\title{
PUBLIC INVESTMENTS AND POVERTY REDUCTION
}

\author{
Paul Dorosh, James Thurlow, Frehiwot Worku Kebede, \\ Tadele Ferede, and Alemayehu Seyoum Taffesse
}

\section{Introduction}

Ethiopia's agricultural sector has grown rapidly in the past decade due to a doubling in the use of modern inputs (chemical fertilizers and improved seeds), significant land expansion, increased labor use, and a 2.3 percent per year growth in total factor productivity (TFP) (see Chapter 2; Bachewe et al. 2018). At the same time, there has been a substantial spatial and structural transformation of the economy. Ethiopia's urban population has more than doubled in the past 20 years from 7.3 million in 1994 to 18.3 million in 2016 (see Chapter 12), nonagricultural employment and output have grown rapidly, and the shares of nonagricultural sectors (especially services) in both overall employment and GDP have risen (see Chapter 11). Moreover, household welfare indicators have improved dramatically: rural poverty fell from 45.0 percent to 23.5 percent from 1999/2000 to 2015/2016 (NPC 2016), and the prevalence of stunting in young children, an indicator of chronic malnutrition, fell from 58 percent in 2000 to 40 percent in 2014.

Agricultural growth played a crucial role in Ethiopia's economic development over the past two decades, particularly in the early 2000s under the agricultural development-led industrialization (ADLI) strategy that formed the basis for subsequent medium-term development plans, such as the Plan for Accelerated and Sustained Development to End Poverty (PASDEP) (2005/2006-2009/2010), the Growth and Transformation Plans (GTP I, 2010/2011-2014/2015 and GTP II, 2015/2016-2019/2020), and Ethiopia's participation in the Comprehensive Africa Agriculture Development Programme (CAADP) of the African Union. Substantial public investment in agriculture and rural development has continued under GTP I and GTP II; agricultural expenditures grew by an average of 10.1 percent per year from 2009/2010 to 2014/2015 (Figure 13.1 and Table 13.1). Nonetheless, the focus of the development strategy has increasingly shifted toward commercial 
FIGURE 13.1 Real public expenditures on agriculture and rural development in Ethiopia, 2007/2008-2015/2016 (billion 2015/2016 birr)

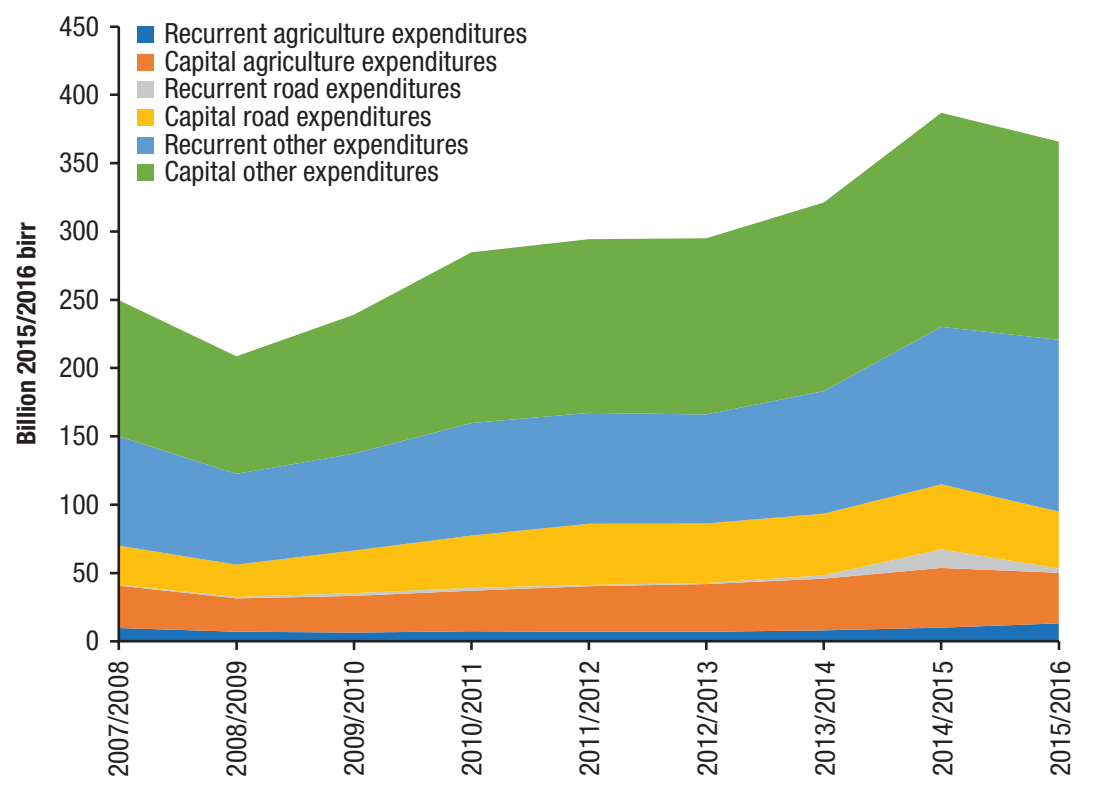

Source: Ethiopia, MoFED (various years) and authors' calculations.

TABLE 13.1 Real public expenditures on agriculture and rural development in Ethiopia, 2009/2010 and 2014/2015 (billion 2015/2016 birr)

\begin{tabular}{lccc}
\hline Sector & 2009/2010 & 2014/2015 & $\begin{array}{c}\text { Annual } \\
\text { growth (\%) }\end{array}$ \\
\hline Agriculture & 33.3 & 53.7 & 10.1 \\
Recurrent & 6.4 & 10.0 & 9.3 \\
Capital & 26.8 & 43.7 & 10.2 \\
Roads & 33.2 & 61.2 & 13.0 \\
Other & 172.6 & 271.9 & 9.5 \\
Total & 239.1 & 386.8 & 10.1 \\
Agriculture share (\%) & 13.9 & 13.9 & 0.0 \\
Roads share (\%) & 13.9 & 15.8 & 0.4 \\
\hline
\end{tabular}

Source: Ethiopia, MoFED (various years) and authors' calculations. 
agriculture and nonagricultural growth and employment as the key engines of economic development.

Spurring economic growth was not the only rationale for heavy investments in agriculture in the past two decades, however. Increasing agricultural productivity and incomes was also seen as a key means of reducing poverty. Economic analysis of the impacts of public spending on agriculture suggested that investing 10 percent of public expenditures on agriculture and rural development would lead to major reductions in poverty, not only in Ethiopia but in most of Africa south of the Sahara (Diao et al. 2013; Dorosh and Thurlow 2013b). Other analyses showed that because most of Ethiopia's poor lived in rural areas and derived much of their incomes from agriculture, investments that raised productivity in agriculture (and in small towns) reduced poverty faster than did investments in urban areas (Dorosh and Thurlow 2013a, 2014).

However, the effectiveness of agricultural growth in reducing poverty at the national level depends on several factors, including the productivity of the investments themselves as well as the structure of the economy-the level of urbanization, the share of agricultural sector in overall output and employment, and the main sources of incomes of the poor, among other factors. As these factors change over time, so will the impacts of agricultural investments on growth and poverty. Thus, while agricultural investments may have been highly effective in reducing poverty in the early 2000s, there remains a question as to whether this is still the case.

This chapter explores these issues using an economywide computable general equilibrium (CGE) model. First, the chapter describes the structure of Ethiopia's economy as reflected in the database used for the modela 2010/2011 social accounting matrix (SAM). The basic structure of the model is outlined, and the design of the base run and simulations are described. We present the results of four alternative investment scenarios with faster investment in (1) economic sectors in large cities; (2) crop agriculture; (3) rural nonfarm sectors; and (4) livestock. The final section includes a summary and conclusion, along with important caveats and areas for future research.

\section{Policy Context and the Structure of Ethiopia's Economy}

Priorities for public investments in Ethiopia have gradually changed over time along with the changing structure of Ethiopia's economy and the success of 
past development plans in raising incomes and lowering poverty. In light of these achievements, Ethiopia's overarching growth target is now to become a lower-middle income country by 2025 with improved agricultural and manufacturing productivity. Part of this overall economic vision for the country, the GTP II, aims for Ethiopia to be a hub for light manufacturing in Africa.

Nonetheless, the ADLI strategy adopted in the early 1990 s remains a core part of Ethiopia's development strategy. ADLI's main objective has been to enhance productivity growth in agriculture through better access to modern agricultural inputs, extension services, and road connectivity, and to use the resulting growth in agriculture as the basis for industrial expansion. The underlying premise is exploiting the country's comparative advantage in agro-processing industries as productivity growth in agriculture will facilitate the reliable and low-cost supply of agricultural inputs for manufacturers (NPC 2016). To facilitate these cross-sectoral linkages, the GTP II outlines investments and policies related to agriculture, (agro-)industry, regional development, and urbanization.

\section{Sector Specific Investment Initiatives}

Within agriculture, GTP II focuses on several key aspects, including the following:

- Promoting the productivity and quality of staple food crops production;

- Supporting development of high-value crops, industrial inputs, and export commodities;

- Improving investment in irrigated agriculture, horticulture, fruits and vegetables, and livestock and in fisheries development; and

- Facilitating participation of educated young farmers and private investors in the sector.

To improve the competitiveness, quality, and productivity of the agricultural sector, the GTP II continues policies of development and dissemination of available technologies, investments in irrigation, provision of extension services, and scaling up of best practices of model smallholder farmers (NPC 2016). In particular, the plan includes development of more than 4 million hectares of smallholder irrigated land and to complement investments in dams and medium- and large-scale irrigation. These small-, medium-, and large-scale irrigation interventions are expected to enhance agricultural productivity and ensure stability of agricultural production. Investments in livestock include 
improving the genetics of livestock, expanding livestock health coverage, enhancing service quality and control, and improving supply of livestock feed.

Complementary to these agricultural investments, the Ministry of Industry's industrial development roadmap (IDR) for 2013-2025 and the Industrial Development Strategic Plan (IDSP) together define strategies, programs, and projects to promote industrialization. To complement the public investments, the strategic plan also aims to encourage domestic private-sector investment as well as to attract Foreign Direct Investment (FDI) through the following:

- Expansion of special economic zones or specialized industrial parks with the required infrastructure and streamlined public procedures as well as fiscal and trade policy incentives;

- Provision of more efficient trade logistics and transport services and energy supply; and

- Supply of land, credit, and foreign exchange mainly through an industrial parks approach.

In particular, the establishment of integrated industrial development parks across the country is designed to ease logistics hurdles and other constraints though investments in physical infrastructure and the establishment of support services, including one-stop-shop services for investors located in the designated industrial parks. ${ }^{1}$ These parks are dedicated for specific sectors, such as textile and apparel, leather and leather products, pharmaceuticals, and agro-processing. The Ethiopian government also plans to establish additional industrial parks to boost manufacturing industries at Bahir Dar, Jimma, and Adama. The government of Ethiopia with support from the United Nations Industrial Development Organization (UNIDO) has developed a master plan for integrated agro-industrial parks (IAIPs) in four regions-namely Bure (Amhara region), Baeker (Tigray region), Bulbula (Oromia region), and Yirgalem (SNNP region) - to advance inclusive and sustainable industrialization and rural transformation (UNIDO 2018).

1 Recently, new industrial parks have become operational, including Bole Lemi I, Hawassa, Kombolcha, and Mekelle. There are also a number of upcoming industrial parks in Ethiopia, including Bole Lemi II, Kilinto, Adama, Dire Dawa, Arerti, and Debre Berhan industrial parks. See Schmidt et al. (2018). 
The government of Ethiopia has also developed a master plan for rural transformation centers (RTCs), which serve as raw material aggregation points in the catchment areas (100 kilometer radius) of each IAIP. Rural transformation centers are expected to provide several functions, including warehouses, input supply, sorting, grading, extension services, pre-processing activities, and microfinance. Development of industrial parks enjoys strong government support. These parks are located along key economic corridors, are connected to ports, and are supported by various types of infrastructure, including airports, railway lines, dry ports, and universities.

These industrial sectoral policies and investments implicitly focus on urban centers (including secondary cities) and relate closely to the national urban development policy of 2005. Although Ethiopia's urban population share is low, this is set to change dramatically. The urban population is projected to nearly triple from 15.2 million in 2012 to 42.3 million in 2037, growing at 3.8 percent a year. This growth rate places Ethiopia among the fastest urbanizing countries in Africa south of the Sahara (Ethiopia, CSA 2013). According to the Ethiopia Urbanization Review (EUR), Ethiopia will experience rapid urbanization at about 5.4 percent a year, higher than CSA's estimate (World Bank 2015b). Key factors driving urbanization in Ethiopia include migration to new towns and urban centers, reclassification of rural villages as urban centers, and formal expansion of existing urban boundaries to incorporate nearby settlements. These all accelerate urbanization, which will change the structure and location of economic activity from rural agriculture to more diversified and larger urban industrial and service sectors.

To support sustainable urban development, the GTP II outlines an integrated urban housing development program, an integrated urban infrastructure program (including urban green infrastructure), urban land development and management, solid waste management, development of small towns, and strengthening of rural-urban linkages. Among the major programs is the Urban Local Government Development Program (ULGDP), financed by the World Bank, that supports improved institutional performance in the planning, delivery, and sustained provision of urban services and infrastructure by local governments. ${ }^{2}$ The second phase of ULGDP (2014-2019) is aligned with new government urban policies and strategies, such as the Ethiopian Cities Prosperity Initiative, 2013/2014-2025, and is designed to sustain urban

2 The first phase of the program included 18 urban local governments and Addis Ababa with a budget envelope of US $\$ 416$ million. The first phase of the program begun in 2008 was supported by a US $\$ 300$ million Specific Investment Loan (World Bank 2015a). 
infrastructure and services. The program intends to address urban infrastructure gaps, improve urban productivity, and strengthen the institutions of both the urban local governments involved in service delivery and the regions and the Ministry of Urban Development and Housing.

\section{The Structure of the Ethiopian Economy}

The main database for the economywide analysis conducted for this study is a 2010-2011 social accounting matrix (SAM) for Ethiopia, a consistent set of accounts representing economic flows for production activities; commodity flows; incomes and expenditures of households, government, and other institutions; transactions with the rest of the world; savings; and investment. ${ }^{3}$ This 2010-2011 SAM was constructed using data from the national accounts, sectoral production and prices, the balance of payments, and the 2010-2011 national Household Consumption Expenditures Survey (HCES) (Ethiopia, CSA 2012). ${ }^{4}$

This 2010-2011 Ethiopia SAM includes 69 production sectors split across six geographical areas: five rural areas (including towns), based on agroecologies (elevation and rainfall) and cropping patterns, and one urban category (cities with populations of 50,000 or more). In each of these six areas, rural and urban labor are disaggregated by education/skill levels (no education, primary, secondary, and tertiary education) and households are disaggregated by per capita expenditure quintiles, with poor households defined as those in the bottom 40 percent of the per capita expenditure distribution (see Appendix 13A).

Agricultural land in the SAM is disaggregated across five agroecological zones: (1) drought prone, highland; (2) moisture reliable, highland-cereal; (3) moisture reliable, highland-enset (mostly in the SNNP region); (4) humid moisture reliable, lowland; and (5) drought prone, lowland and pastoralist (Figure 13.2). The highland moisture reliable zones (2 and 3) account for more than 90 percent of the national cereal area and production. We define highlands as land 1,500 or more meters above sea level. Highland areas with a ratio of mean to standard deviation of rainfall greater than or equal to 7.5 are deemed moisture reliable. For the lowlands, areas with average rainfall less than 500 millimeters per year are classified as drought prone/pastoralist.

3 To a large extent, the regional structure of this SAM follows that of the EDRI/IFPRI 20052006 Ethiopia SAM (EDRI 2009).

4 Household-level data from the 2015-2016 HCES was not available at the time when this SAM was constructed. 


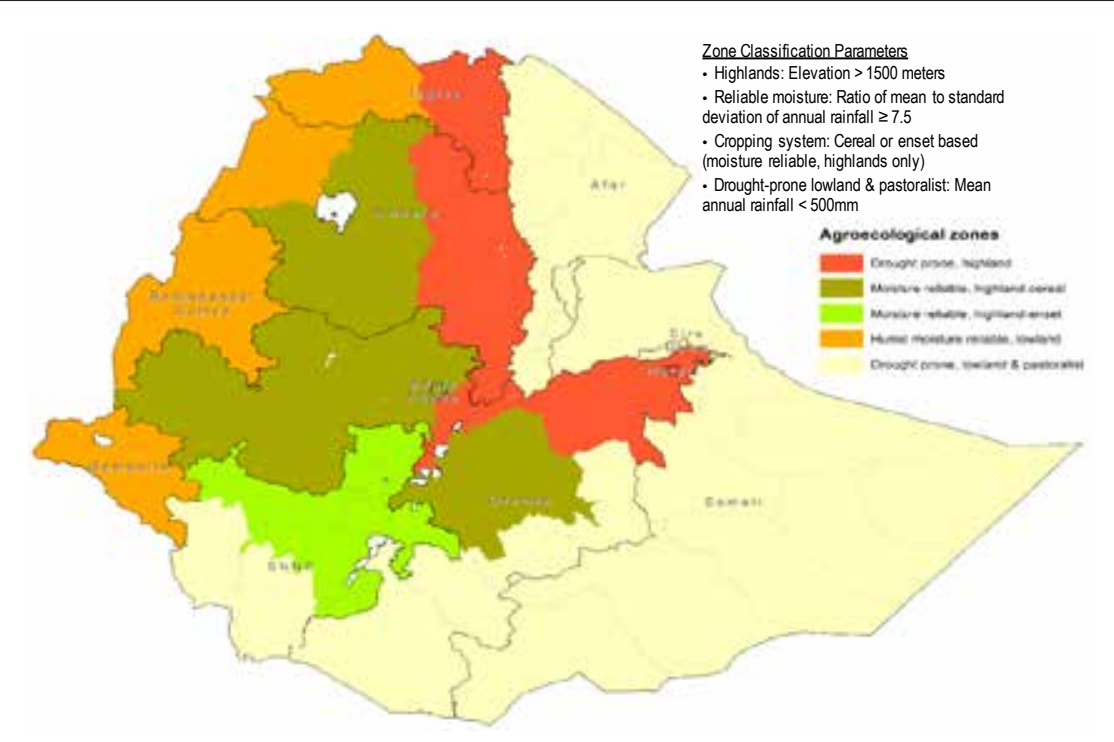

Source: EPAU and IFPRI (2017).

Note: SNNP = Southern Nations, Nationalities, and Peoples.

Table 13.2 presents estimates of incomes and expenditures by household group by geographical area for $2015 / 2016$. $^{5}$ As shown, rural households accounted for 81.8 percent of the population (70.9 million of 86.7 million people) and 85.6 percent of the country's poor ( 29.7 million of 34.7 million poor people). Overall, total expenditures by the poor (the poorest 40 percent of the population) are estimated to have accounted for less than 10 percent of total household expenditures in Ethiopia (566.6 billion birr of 6,534 billion birr). Per capita expenditures of the rural poor (3,332 birr per person) were only 51 percent of the national average $(6,534$ birr per person) and 25 percent of urban nonpoor (13,553 birr per person) (Figure 13.3).

As shown in Table 13.3, both rural poor and nonpoor households obtain most of their incomes from labor. For rural poor households, almost all of this is from unskilled labor (which is 50.2 percent of their total incomes). ${ }^{6}$ Returns to land and livestock capital account for another 24.1 percent and 9.7 percent of their incomes, respectively. They get very little of their income from nonagricultural capital (enterprise incomes) or other sources. Urban

5 These estimates are the results of the baseline simulation described below in this chapter.

6 In the SAM, "unskilled labor" is defined as workers who have not completed primary school. 


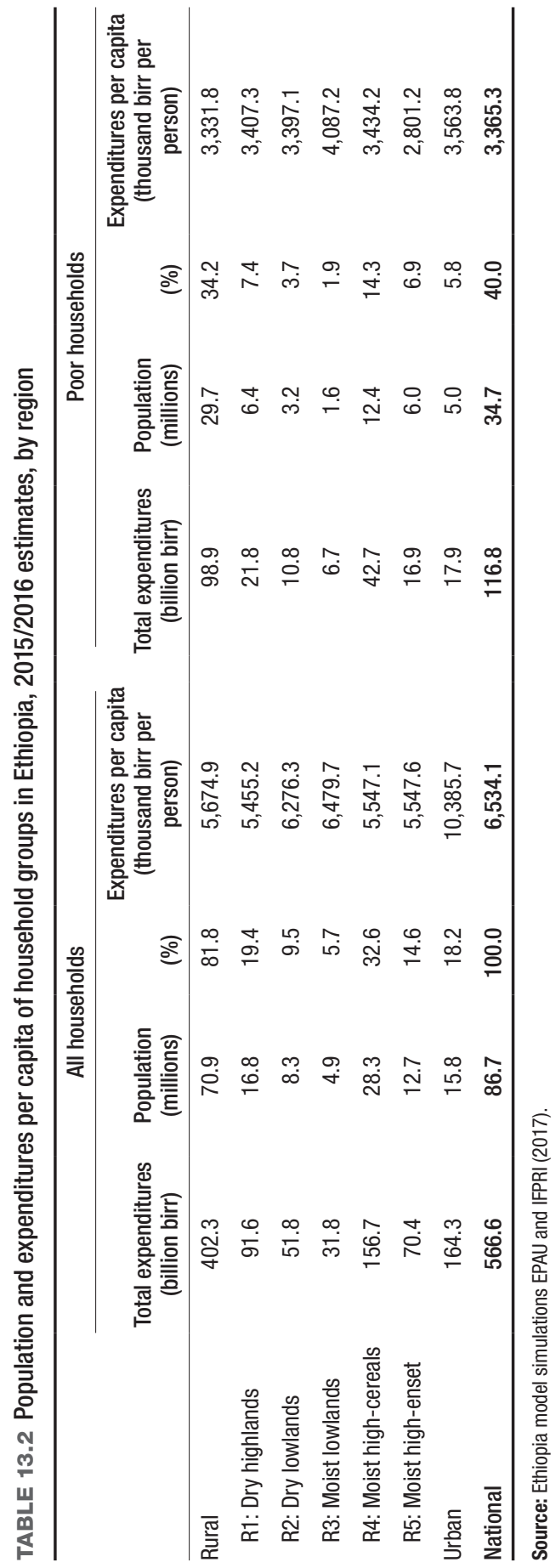


FIGURE 13.3 Estimated per capita expenditures of poor and nonpoor households in Ethiopia, 2015/2016

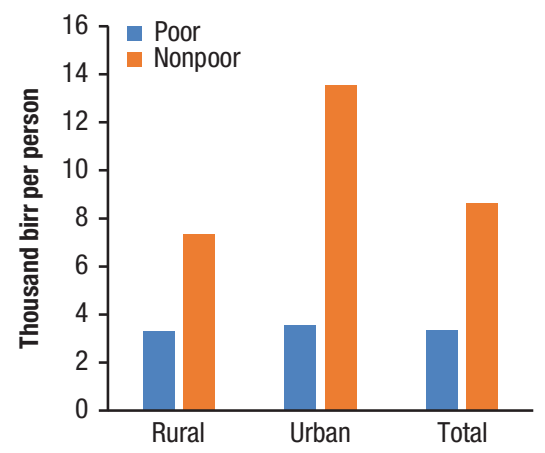

Source: Model simulations based on EPAU and IFPRI (2017).

TABLE 13.3 Factor income sources by household groups in Ethiopia, shares of total income, 2010/2011

\begin{tabular}{lccccccccc}
\hline & $\begin{array}{c}\text { Unskilled } \\
\text { labor }\end{array}$ & $\begin{array}{c}\text { Skilled } \\
\text { labor }\end{array}$ & Land & $\begin{array}{c}\text { Agri- } \\
\text { cultural } \\
\text { capital }\end{array}$ & $\begin{array}{c}\text { Livestock } \\
\text { capital }\end{array}$ & $\begin{array}{c}\text { Enter- } \\
\text { prises }\end{array}$ & $\begin{array}{c}\text { Govern- } \\
\text { ment }\end{array}$ & $\begin{array}{c}\text { Rest of } \\
\text { world }\end{array}$ & Total \\
\hline Rural poor & 0.502 & 0.050 & 0.241 & 0.021 & 0.097 & 0.082 & 0.000 & 0.006 & 1.000 \\
Rural nonpoor & 0.296 & 0.081 & 0.123 & 0.010 & 0.048 & 0.416 & 0.001 & 0.025 & 1.000 \\
Urban poor & 0.359 & 0.238 & 0.000 & 0.000 & 0.000 & 0.399 & 0.000 & 0.004 & 1.000 \\
Urban nonpoor & 0.071 & 0.217 & 0.000 & 0.000 & 0.000 & 0.691 & 0.001 & 0.019 & 1.000 \\
All households & 0.291 & 0.105 & 0.118 & 0.010 & 0.046 & 0.408 & 0.001 & 0.020 & 1.000 \\
Total & 0.291 & 0.068 & 0.081 & 0.006 & 0.031 & 0.264 & 0.047 & 0.013 & 1.000 \\
\hline
\end{tabular}

Source: Dorosh et al. (2018).

Note: Poor households are defined as those in the bottom 40 percent of the national per capita expenditure distribution. Agricultural capital includes tractors, plows, and so on. Livestock capital includes both livestock and poultry. Enterprises include informal household enterprises.

poor households likewise derive a large share of their incomes from labor, 35.9 percent from unskilled labor and 23.8 percent from skilled labor. Urban poor households also differ from the rural poor in that they obtain a large share of their incomes (39.9 percent) from enterprises (almost exclusively informal enterprises).

Rural nonpoor households differ from rural poor households, not only in the overall amount of land cultivated, livestock capital, and the magnitude of their incomes but also in the relatively large share of income deriving from enterprises (41.6 percent), including implicit returns on capital from incomes earned in marketing. Finally, the urban nonpoor get only 28.8 percent of their 
incomes from labor (only 7.1 percent of their incomes from unskilled labor); 69.1 percent of their incomes derive from returns to enterprise capital. (Note that remittances and foreign transfers account for only 2.0 percent of household incomes overall.)

\section{Methodology: Model Structure and Equations}

In this analysis we use a neoclassical recursive dynamic computable general equilibrium (CGE) model (Dervis, de Melo, and Robinson 1982; Diao and Thurlow 2013; Dorosh and Thurlow 2013b) with modifications for effects of agglomeration and congestion on total factor productivity in urban areas (Dorosh and Thurlow 2012, 2014). The model consists of both behavioral equations that describe the economic decisions related to production, marketing, consumption, and so on of economic agents (firms, households, and institutions) and structural equations that specify accounting relationships between the incomes and expenditures of individual agents and within the macroeconomy. ${ }^{7}$

In the model, producers choose levels of inputs and outputs, given the technology available, as determined by constant elasticity of substitution functions that allow substitution between factors based on relative factor price changes. Demand by producers for intermediate inputs is determined by fixed input-output coefficients. Consumer demand is determined by (linear expenditure system) demand equations that implicitly maximize utility given budget constraints. Income (expenditure) elasticities are estimated using data from the 2010/2011 HCES. National market prices adjust to clear overall supply and demand for each product.

Domestically produced goods and services are modeled as imperfect substitutes with goods and services that are exported or imported. ${ }^{8}$ World prices are fixed (exogenous) under the assumption that changes in Ethiopia's demand for imports or supply of exports do not affect world prices (that is, a small country assumption). We model six regional labor markets and four types of labor. Total supply of labor is fixed with each year's simulation, with wage rates

7 See Diao and Thurlow (2013) and Dorosh and Thurlow (2013b and 2014) for more details on the basic model equations and parameters.

8 We use Armington (Constant Elasticity of Substitution) functions to model imperfect substitution between imported and domestic goods and services (Armington 1969) and constant elasticity of transformation (CET) functions to model imperfect substitution between exported and domestic goods. Parameters are based on Dimaranan (2006). 
adjusting in each period to equate supply and demand in each region and each type of labor.

Investment is determined by the total supply of savings in the economy. Given fixed marginal propensities to save for each household type, increases in incomes result in higher levels of savings and investment. Tax rates and level of government recurrent spending are also fixed, with net government savings (the difference between government revenues and recurrent spending) adding to the total pool of savings in the economy. Foreign capital inflows (foreign savings) are assumed to be fixed. The nominal exchange rate adjusts to clear the foreign exchange market. The domestic price index is the model's numeraire.

Between periods we update parameters based on long-term trends to reflect changes in factor supplies and productivity, household population growth, government spending, and foreign capital inflows. Capital stocks within each sector and region are updated each year to reflect depreciation and investments from the previous period. Given that investment in capital responds to relative returns across sectors, sectors with above-average profits receive a larger share of new capital stocks than their share of installed capital in the previous period.

We model internal migration across regions between periods (years) in response to wage differentials. The migration rates are estimated by assuming the same natural population growth (fecundity minus morbidity) in urban and rural areas and then scaling migration to match projected population growth rates (natural population growth plus net migration). We model urban agglomeration effects of increased urban population density using an agglomeration elasticity of 0.08 (the percentage change in urban TFP resulting from a 1 percent increase in population density) (Henderson and Wang 2005; Dorosh and Thurlow 2012). Urban TFP also depends on congestion, with a congestion elasticity of 0.10 (the percentage increase in urban TFP gain from a 1 percent increase in public capital per capita).

We model the return on agricultural and rural investments using an agricultural TFP to public agricultural spending elasticity of 0.3 from Benin, Fan, and Johnson (2012). A similar rate of return is used for the rural nonfarm TFP (note that nonfarm GDP is 42 percent of rural GDP). Population and labor (by zone) grow at different (exogenous) rates. Total cropland (by zone) grows at fixed rates, but individual crops' areas are endogenously allocated according to relative profitability.

9 Note that in the base run and most simulations, the growth rate of area cultivated in all three highland zones is set to zero for 2027-2040, reflecting severe land constraints. 


\section{Model Simulations}

To analyze the implications of alternative public investment strategies, we first construct a baseline simulation and then model four alternative scenarios. The baseline, as well as each alternative scenario, assumes the same overall level of foreign savings (net capital inflows) and public investment; only the allocation of investments to sectors changes across simulations. ${ }^{10}$ The five simulations are the following:

- Baseline. Business-as-usual but with reduced foreign savings since growth over the period 2011-2016 was driven to a large extent by large-scale foreign borrowing and other capital inflows and likely is not sustainable.

- Cities. Faster urbanization in cities with populations of more than 50,000 in 2011; increased foreign savings relative to baseline.

- Agriculture. Increased investment in agriculture with baseline foreign savings.

- Rural nonfarm (RNF). Faster growth in the rural nonfarm sector (concentrated in small towns with populations of fewer than 50,000) and increased foreign savings.

- Livestock and crop shift. Increased concentration of livestock production in the highlands with a corresponding shift in crop area from the rainfallsufficient highlands to the rainfall-sufficient lowlands. ${ }^{11}$

\section{Design of Simulations}

We run the model over the period 2011/2012-2039/2040 (2012-2040). ${ }^{12}$ The first subperiod, 2012-2016, is designed to replicate historical trends and thus is the same for the base run and all policy simulations. Two other subperiods are modeled: period 2 (2017-2026) and period 3 (2027-2040). The baseline simulation models a slowdown in growth of agricultural production,

10 In terms of the modeling of investments, the difference between the cities and the rural nonfarm scenario productivity shocks is the physical location of the capital. Implicitly, however, the actual public investments that raise productivity of industry, transport, trade, and other sectors will differ by location (for example, building feeder roads in rural areas versus flyovers in urban areas).

11 No changes in yields due to changes in rainfall and temperature are assumed in the simulations. As noted in Chapter 4 (Table 4.2), estimated effects of changes in rainfall and temperature on cereal yields are small (1.2 percent or less through 2035).

12 For ease of presentation we adopt the convention that year $t / t+1$ is denoted year $t+1$ (that is, $2010 / 2011=2011)$. 
consistent with recent data. Increases in area cultivated, labor use, use of fertilizer and improved seeds, and TFP accounted for much of the 8.3 percent annual average grain output growth from 2004/2005 to 2015/2016, as area cultivated and yields increased by 2.6 percent and 4.8 percent per year, respectively. However, growth in cereal production decelerated somewhat to only 6.7 percent per year in the second half of this period, as TFP growth slowed to only 0.85 percent per year, a marked deceleration from average TFP growth of 2.02 percent per year in the 2004/2005-2015/2016 period..$^{13}$ Annual increases in cereal area cultivated have also declined, from more than 3 percent in the early 2000s to less than 1 percent in recent years (Figure 13.4).

Moreover, opportunities for future land expansion are limited, however, particularly in the moisture reliable highland zones (including both cereal and enset-based cropping systems) that accounted for 92 percent of cereal area cultivated in 2013/2014 (Schmidt and Thomas 2018). Thus the model simulations assume slow annual growth in area cultivated over the 2017-2040 period: an average of 0.73 percent in the moisture-sufficient highlands and 1.76 percent in the relatively low population density moisture-sufficient lowlands (Tables 13.4 and 13.5; Figure 13.5).

The rate of growth in land area cultivated of most individual crops is a function of the exogenous overall growth in area cultivated in each region and the relative profitability of the crop, although for some crops (sorghum, barley, rice, and industrial crops) the area cultivated is set exogenously. Yield growth rates by crop and region are largely determined by exogenous growth in total factor productivity that approximate recent actual yield growth rates. ${ }^{14}$

The moist highland cereal-producing areas hosted a large proportion (about 42 percent) of total livestock (measured in tropical livestock units) in $2015 / 2016$ due to the concentration of rural population in these areas where the interaction of farming-livestock appears to be strong. Dry and moist lowland areas together accounted for 24 percent of total livestock (Table 13.6 and Figure 13.6). The model assumes a declining average growth rate in livestock numbers from 1.8 percent between 2011 and 2016 to 0.40 percent between

13 These average growth rates do not include 2014/2015, a year for which the data show an 11.0 percent increase in land cultivated. Yield growth is calculated from production and area growth. These figures are adapted from Bachewe et al. (2017). For the 2011-2016 period (without 2014/2015), labor (number of holders), cattle, and fertilizer use grew at 2.89 percent, 1.84 percent, and 12.7 percent per year, respectively.

14 Growth in area cultivated in the base simulation is set to zero for sorghum in all agroecological zones in all three periods. Area growth in barley is set to -1.1 percent per year. Area growth rates for rice and industrial crops (by region) are set to the overall exogenous growth rate of total area in each region (see Appendix Table 13B.1). 
FIGURE 13.4 Annual growth in grain area cultivated and yields in Ethiopia, 2005/20062016/2017 (\%)

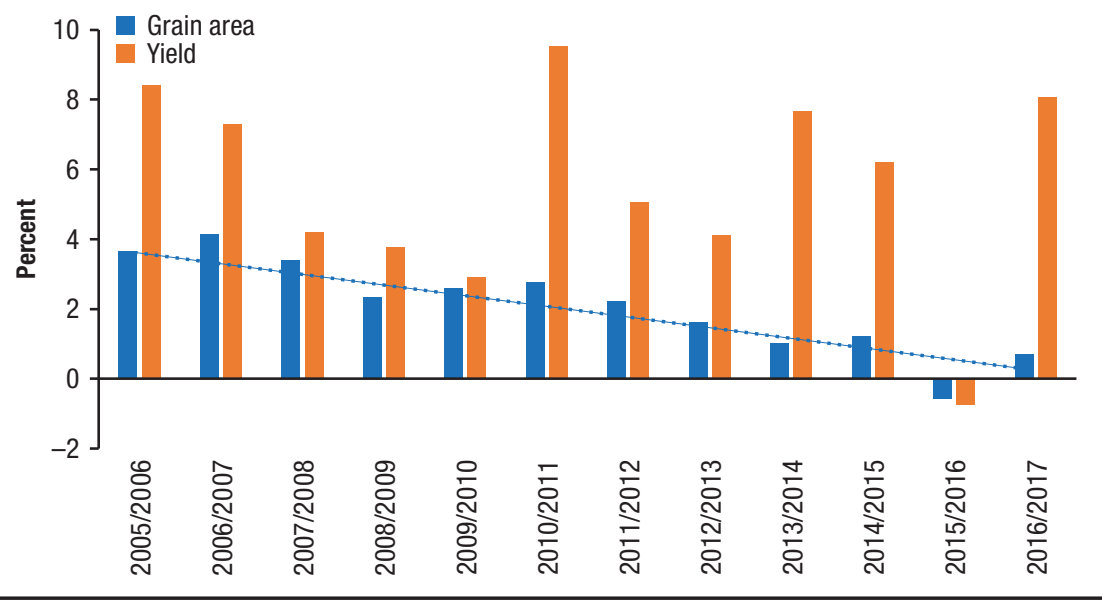

Source: Authors' calculations from agricultural sample survey data, Ethiopia, CSA (various years).

TABLE 13.4 Total area cultivated estimates from selected model simulations in Ethiopia by region, 2039/2040 (million hectares)

\begin{tabular}{lcccc}
\hline & 2015/2016 & S0-Baseline & S2-Agriculture & S4-Livestock \\
\hline R1: Dry highlands & 4.16 & 3.85 & 3.85 & 3.70 \\
R2: Dry lowlands & 1.14 & 1.11 & 1.25 & 1.29 \\
R3: Moist lowlands & 1.28 & 1.66 & 2.34 & 4.83 \\
R4: Moist high cereals & 10.66 & 10.32 & 10.32 & 8.08 \\
R5: Moist high enset & 3.22 & 2.86 & 2.86 & 2.72 \\
Total & 20.46 & 19.81 & 20.62 & 20.63 \\
\hline
\end{tabular}

Source: Dorosh et al. (2018).

Note: S4-Livestock denotes the livestock and crop shift scenario.

2026 and 2040. This assumption of a declining herd size is consistent with the government's focus on improving the productivity of the livestock sector and reducing the number of herds as articulated in the Climate Resilient Green Economy (CRGE) strategy (Ethiopia 2011).

Labor supply and population growth are set exogenously to an average of 2.04 percent in all simulations (Table 13.7). ${ }^{15}$ Labor supply in rural areas

15 Total labor supply growth is set to 2.58 percent, 2.33 percent, and 1.83 percent per year in periods 1,2 and 3 , respectively. 
TABLE 13.5 Annual growth rates and share of total area cultivated in Ethiopia, estimates from selected model simulations, by region and subperiod

\begin{tabular}{|c|c|c|c|c|c|c|}
\hline \multirow[b]{2}{*}{ Growth rate (\%) } & \multicolumn{2}{|c|}{ S0-Baseline } & \multicolumn{2}{|c|}{ S2-Agriculture } & \multicolumn{2}{|c|}{ S4-Livestock ${ }^{a}$} \\
\hline & $\begin{array}{c}2015 / 2016- \\
2025 / 2026\end{array}$ & $\begin{array}{l}2025 / 2026- \\
2039 / 2040\end{array}$ & $\begin{array}{c}2015 / 2016- \\
2025 / 2026\end{array}$ & $\begin{array}{c}2025 / 2026- \\
2039 / 2040\end{array}$ & $\begin{array}{l}2015 / 2016- \\
2025 / 2026\end{array}$ & $\begin{array}{c}2025 / 2026- \\
2039 / 2040\end{array}$ \\
\hline R1: Dry highlands & 0.40 & 0.00 & 0.40 & 0.00 & 0.00 & 0.00 \\
\hline R2: Dry lowlands & 1.00 & 0.80 & 2.00 & 1.00 & 3.00 & 0.40 \\
\hline R3: Moist lowlands & 2.00 & 1.50 & 4.00 & 3.00 & 9.90 & 4.80 \\
\hline R4: Moist high cereals & 1.00 & 0.50 & 1.00 & 0.50 & -0.20 & -0.75 \\
\hline R5: Moist high enset & 0.50 & 0.00 & 0.50 & 0.00 & 0.00 & 0.00 \\
\hline Total: All Ethiopia & 0.86 & 0.41 & 0.99 & 0.57 & 1.13 & 0.28 \\
\hline Share of total area (\%) & $2025 / 2026$ & $2039 / 2040$ & $2025 / 2026$ & $2039 / 2040$ & $2025 / 2026$ & $2039 / 2040$ \\
\hline R1: Dry highlands & 20.3 & 19.5 & 19.9 & 18.7 & 19.1 & 17.9 \\
\hline R2: Dry lowlands & 5.4 & 5.6 & 5.8 & 6.0 & 6.4 & 6.3 \\
\hline R3: Moist lowlands & 7.5 & 8.4 & 9.0 & 11.3 & 15.6 & 23.4 \\
\hline R4: Moist high cereals & 51.7 & 52.1 & 50.6 & 50.0 & 44.9 & 39.2 \\
\hline R5: Moist high enset & 15.1 & 14.5 & 14.8 & 13.9 & 14.0 & 13.2 \\
\hline Total: All Ethiopia & 100.0 & 100.0 & 100.0 & 100.0 & 100.0 & 100.0 \\
\hline \multirow{3}{*}{$\begin{array}{l}\text { Total area } \\
\text { (million hectares) }\end{array}$} & 19.0 & 19.8 & 19.4 & 20.6 & 19.4 & 20.6 \\
\hline & \multicolumn{3}{|c|}{$\begin{array}{c}\text { Total area } \\
\text { (million hectares, 2039/2040) }\end{array}$} & \multicolumn{3}{|c|}{$\begin{array}{c}\text { Growth rate: } \\
\text { 2015/2016-2039/2040 (\%) }\end{array}$} \\
\hline & $\begin{array}{l}\text { S0- } \\
\text { Baseline }\end{array}$ & $\begin{array}{l}\text { S2-Agri- } \\
\text { culture }\end{array}$ & $\begin{array}{c}\text { S4- } \\
\text { Livestock }^{\mathrm{a}}\end{array}$ & $\begin{array}{l}\text { S0- } \\
\text { Baseline }\end{array}$ & $\begin{array}{l}\text { S2-Agri- } \\
\text { culture }\end{array}$ & $\begin{array}{c}\text { S4- } \\
\text { Livestock }^{\mathrm{a}}\end{array}$ \\
\hline R1: Dry highlands & 3.85 & 3.85 & 3.70 & -0.32 & -0.32 & -0.48 \\
\hline R2: Dry lowlands & 1.11 & 1.25 & 1.29 & -0.13 & 0.37 & 0.52 \\
\hline R3: Moist lowlands & 1.66 & 2.34 & 4.83 & 1.09 & 2.54 & 5.68 \\
\hline R4: Moist high cereals & 10.32 & 10.32 & 8.08 & -0.14 & -0.14 & -1.15 \\
\hline R5: Moist high enset & 2.86 & 2.86 & 2.72 & -0.49 & -0.49 & -0.69 \\
\hline Total: All Ethiopia & 19.81 & 20.62 & 20.63 & -0.14 & 0.03 & 0.03 \\
\hline
\end{tabular}

Source: Dorosh et al. (2018).

Note: Growth rates for area cultivated for simulations S1 (urban) and S3 (rural nonfarm) are the same as the base simulation. a. S4 Livestock denotes the livestock and crop shift simulation. 
FIGURE 13.5 Estimated area cultivated by region in Ethiopia, from selected model simulations, 2039/2040 (million hectares)

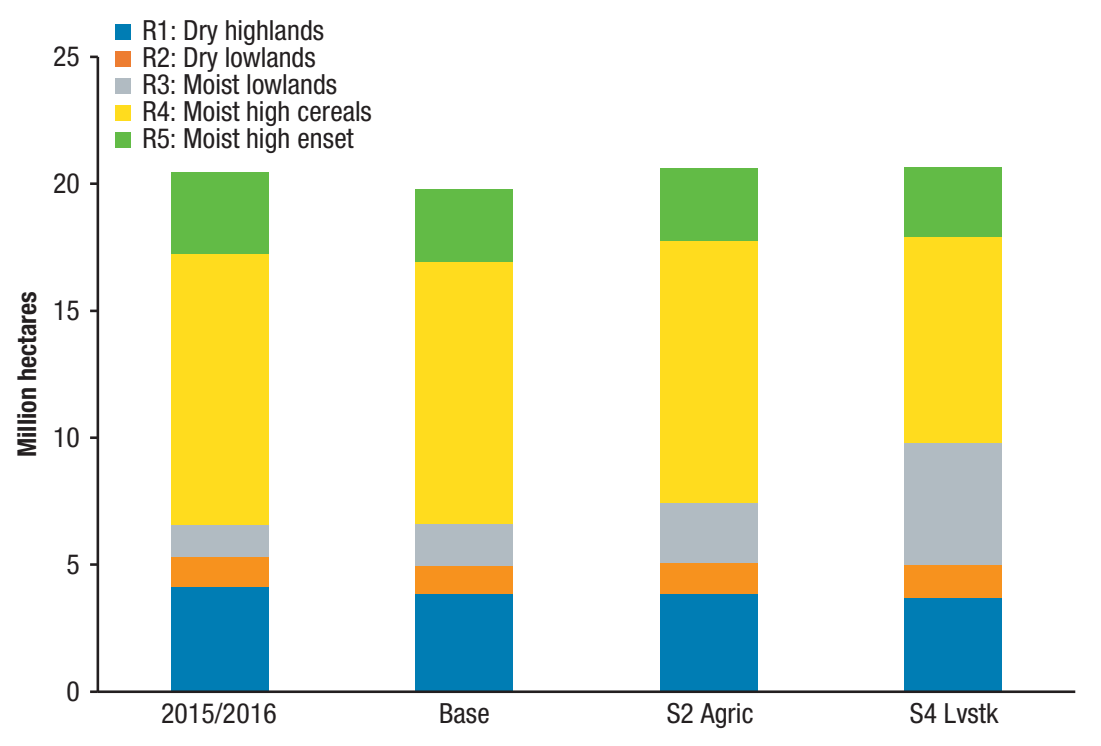

Source: Model simulations.

Note: Growth rates for area cultivated for Simulations S1 (cities) and S3 (rural nonfarm) are the same as the base simulation. S2 Agric = Increased crop agriculture productivity. S4 Lvstk = Increased livestock productivity with expanded crop area in lowlands.

grows at an average annual rate of 1.70 percent per year and 3.30 percent per year in urban areas. Growth rates by rural versus urban regions in the policy simulations vary somewhat, however, because of endogenous changes in migration. $^{16}$

Growth in nonagricultural sectors is a function of growth in factors of production (land, labor, and capital) along with exogenous TFP growth (technical change) specified for each sector and region. In the base scenario, average TFP growth rates for agriculture are 2.50 percent per year from 2016/2017 to $2026 / 2027$, but then slow to only 1.00 percent per year from $2026 / 2027$

16 Population growth rates in the base simulation are derived from the CSA population projections. Overall, population growth slows from an average of 2.41 percent per year in period 1 (2010/2011-2016/2017) to 2.13 percent in period $2(2017 / 2018-2026 / 2027)$ and 1.81 percent in period 3 (2027/2028-2036/2037). Annual average urban population growth rates are much higher, reflecting substantial rural-urban migration (4.94 percent in period 1 and 3.86 percent in period 3 ) as compared with rural population growth rates (1.98 percent in period 1 and 1.16 percent in period 3). See Schmidt et al. (2018) for a discussion of population growth and urbanization projections. 
TABLE 13.6 Livestock by region in Ethiopia, 2015/2016 (thousands of tropical livestock units)

\begin{tabular}{lrrrrr}
\hline Region & Cattle & $\begin{array}{c}\text { Sheep and } \\
\text { goats }\end{array}$ & $\begin{array}{c}\text { Other large } \\
\text { animals }\end{array}$ & Poultry & Total \\
\hline R1: Dry highlands & 6,950 & 1,371 & 1,656 & 130 & 10,107 \\
R2: Dry lowlands & 4,809 & 1,524 & 1,358 & 38 & 7,728 \\
R3: Moist lowlands & 4,221 & 582 & 455 & 97 & 5,354 \\
R4: Moist high cereals & 17,629 & 1,764 & 2,913 & 247 & 22,554 \\
R5: Moist high enset & 6,346 & 547 & 614 & 91 & 7,598 \\
Total: All Ethiopia & 39,955 & 5,788 & 6,997 & 601 & 53,341 \\
\hline Shares within zone & & & & & \\
R1: Dry highlands & 0.688 & 0.136 & 0.164 & 0.013 & 1.000 \\
R2: Dry lowlands & 0.622 & 0.197 & 0.176 & 0.005 & 1.000 \\
R3: Moist lowlands & 0.788 & 0.109 & 0.085 & 0.018 & 1.000 \\
R4: Moist high cereals & 0.782 & 0.078 & 0.129 & 0.011 & 1.000 \\
R5: Moist high enset & 0.835 & 0.072 & 0.081 & 0.012 & 1.000 \\
Total: All Ethiopia & 0.749 & 0.109 & 0.131 & 0.011 & 1.000 \\
\hline
\end{tabular}

Source: Ethiopia, CSA data and authors' calculations.

FIGURE 13.6 Number of livestock in Ethiopia, 2015/2016 (thousands of tropical livestock units)

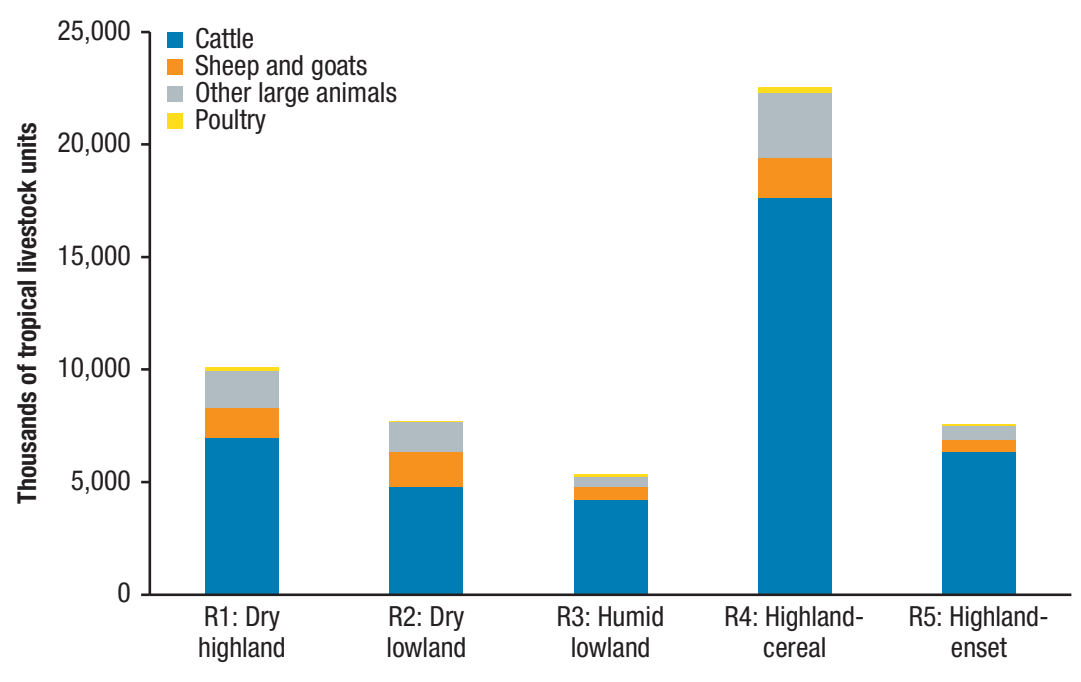

Source: Ethiopia, CSA data and authors' calculations. 
TABLE 13.7 Economywide model results: Growth drivers

\begin{tabular}{lccccc}
\hline & \multicolumn{5}{c}{ Average annual growth rates, 2016/2017-2039/2040 (\%) } \\
\cline { 2 - 6 } Variable & $\begin{array}{c}\text { S0- } \\
\text { Baseline }\end{array}$ & $\begin{array}{c}\text { S1- } \\
\text { Cities }\end{array}$ & $\begin{array}{c}\text { S2- } \\
\text { Agriculture }\end{array}$ & $\begin{array}{c}\text { S3- } \\
\text { Rural nonfarm }\end{array}$ & $\begin{array}{c}\text { S4- } \\
\text { Livestock }\end{array}$ \\
\hline National population & 2.04 & 2.04 & 2.04 & 2.04 & 2.04 \\
$\quad$ Rural & 1.70 & 1.70 & 1.71 & 1.71 & 1.71 \\
Urban & 3.30 & 3.32 & 3.29 & 3.27 & 3.29 \\
Total GDP growth & 6.15 & 6.47 & 5.54 & 6.26 & 5.46 \\
Labor supply & 2.04 & 2.04 & 2.04 & 2.04 & 2.04 \\
Land supply & 0.67 & 0.67 & 0.78 & 0.67 & 0.76 \\
Capital accumulation & 7.53 & 7.85 & 6.87 & 7.82 & 6.79 \\
$\quad$ Total factor productivity growth & 6.15 & 6.47 & 5.54 & 6.26 & 5.46 \\
Shares in 2039/2040 & & & & & \\
Foreign capital/GDP (\%) & 24.18 & 24.26 & 22.39 & 24.53 & 21.82 \\
Investment/GDP (\%) & 25.90 & 27.37 & 20.94 & 26.53 & 20.25 \\
\hline
\end{tabular}

Source: Model simulations.

Note: a. Livestock and crop shift scenario

to $2039 / 2040$. TFP growth rates for nonagriculture are 0.50 percent for both periods (Appendix Table 13B.2)..$^{17}$

Growth in capital is determined by overall (domestic and foreign) savings and investment. Much of the growth in the Ethiopian economy in recent years was due to capital growth financed by unsustainable foreign capital inflows that grew at 36.2 percent per year from 2010/2011 through 2015/2016. Moreover, as a result of foreign and domestic borrowing in this period, Ethiopia's total foreign and domestic debt reached 60.3 percent of GDP in 2016/2017.

For this forward-looking analysis, we assume that the balance of payments and debt problems are resolved over time through reduction in foreign borrowing and domestic spending. Thus in the model simulations (2016/2017$2039 / 2040$ ), foreign savings and government foreign income are assumed to decrease by 4.0 percent per year to model moderate levels of investment and overall GDP growth.

17 These TFP growth rates are adjusted to meet target growth rates in overall agricultural GDP and total GDP. 


\section{Baseline Simulation Results}

In the baseline scenario, investment growth slows to 3.7 percent per year and real GDP increases by 6.2 percent per year (Table 13.9). Given the high growth rate of GDP, foreign savings as a share of GDP falls steadily, from 20.9 percent in 2016 to only 0.1 percent in 2039/2040, and the ratio of investment to GDP declines from 49.6 percent to 25.9 percent between 2016 and 2040 (Table 13.8). Agricultural GDP increases by 2.9 percent per year-much

TABLE 13.8 Model simulations: Macroeconomic outcomes

\begin{tabular}{|c|c|c|c|c|c|c|}
\hline Model outcome & $\begin{array}{l}\text { Base } \\
2016\end{array}$ & $\begin{array}{l}\text { Base } \\
2040\end{array}$ & $\begin{array}{l}\text { S1- } \\
\text { Cities } \\
2040\end{array}$ & $\begin{array}{l}\text { S2-Agri- } \\
\text { culture } \\
2040\end{array}$ & $\begin{array}{c}\text { S3-Rural } \\
\text { nonfarm } \\
2040\end{array}$ & $\begin{array}{c}\text { S4- } \\
\text { Livestock }^{\mathrm{a}} \\
2040\end{array}$ \\
\hline \multicolumn{7}{|l|}{ Level (billion 2016/2017 birr) } \\
\hline Absorption & $1,015.5$ & $3,292.7$ & $3,463.7$ & $2,913.1$ & $3,396.7$ & $2,842.6$ \\
\hline Households & 568.1 & $1,858.6$ & $1,928.2$ & $1,732.0$ & $1,912.4$ & $1,694.1$ \\
\hline Investment & 384.6 & 910.3 & $1,011.6$ & 657.2 & 960.5 & 624.7 \\
\hline Government & 62.8 & 523.8 & 523.8 & 523.8 & 523.8 & 523.8 \\
\hline Exports & 128.2 & $1,179.1$ & $1,278.5$ & 961.5 & $1,226.0$ & 928.3 \\
\hline Imports & 336.8 & $1,193.8$ & $1,293.2$ & 976.3 & $1,240.7$ & 943.1 \\
\hline Trade deficit/GDP (\%) & 44.5 & 24.2 & 24.3 & 22.4 & 24.5 & 21.8 \\
\hline Real exchange rate & 48.1 & 31.5 & 28.7 & 36.6 & 30.5 & 36.9 \\
\hline Nominal exchange rate & 99.4 & 62.6 & 56.9 & 73.2 & 60.5 & 73.8 \\
\hline Investment/GDP (\%) & 49.6 & 25.9 & 27.4 & 20.9 & 26.5 & 20.2 \\
\hline Private savings/GDP (\%) & 22.3 & 18.6 & 18.3 & 19.4 & 18.3 & 19.4 \\
\hline Foreign savings/GDP (\%) & 20.9 & 0.1 & 0.1 & 0.2 & 0.1 & 0.2 \\
\hline Government savings/GDP (\%) & 6.3 & 7.2 & 9.0 & 1.4 & 8.1 & 0.7 \\
\hline Growth rate (\%) & 2011-2016 & \multicolumn{5}{|c|}{ 2016-2040 } \\
\hline Absorption & 11.9 & 5.0 & 5.2 & 4.5 & 5.2 & 4.4 \\
\hline Households & 6.6 & 5.1 & 5.2 & 4.8 & 5.2 & 4.7 \\
\hline Investment & 25.1 & 3.7 & 4.1 & 2.3 & 3.9 & 2.0 \\
\hline Government & 9.2 & 9.2 & 9.2 & 9.2 & 9.2 & 9.2 \\
\hline Exports & 8.9 & 9.7 & 10.1 & 8.8 & 9.9 & 8.6 \\
\hline Imports & 15.5 & 5.4 & 5.8 & 4.5 & 5.6 & 4.4 \\
\hline Real exchange rate & 0.1 & -1.7 & -2.1 & -1.1 & -1.9 & -1.1 \\
\hline Nominal exchange rate & -0.1 & -1.9 & -2.3 & -1.3 & -2.0 & -1.2 \\
\hline Domestic price index & -0.2 & -0.2 & -0.2 & -0.1 & -0.2 & -0.1 \\
\hline
\end{tabular}

Source: Model simulations.

Note: a. Livestock and crop shift scenario. 
slower than for industry (6.4 percent per year) or services (7.5 percent per year) (Table 13.9).

Within agriculture, differences in assumed TFP growth by crop (and region) largely determine the growth outlooks for individual crops. In the base simulation, average annual TFP growth rates for maize and wheat (1.68 percent and 1.46 percent, respectively) are significantly higher than those for teff (1.00 percent). Annual growth rates of production for wheat

TABLE 13.9 Model simulations: Sectoral output for Ethiopia

\begin{tabular}{|c|c|c|c|c|c|c|c|c|}
\hline \multirow[b]{2}{*}{ Sector } & \multirow[b]{2}{*}{$\begin{array}{c}\text { Base } \\
2016 \\
\text { (billion } \\
\text { birr) }\end{array}$} & \multirow[b]{2}{*}{$\begin{array}{c}\text { Base } \\
2040 \\
\text { (billion }^{\text {birr) }}\end{array}$} & \multirow[b]{2}{*}{$\begin{array}{l}\text { Base } \\
2040 \\
(\%)^{c}\end{array}$} & \multicolumn{5}{|c|}{ Annual average growth rate (2016-2040) } \\
\hline & & & & $\begin{array}{c}\text { S0- } \\
\text { Baseline } \\
(\%)\end{array}$ & $\begin{array}{c}\text { S1- } \\
\text { Cities } \\
(\%)\end{array}$ & $\begin{array}{l}\text { S2- } \\
\text { Agricul- } \\
\text { ture } \\
(\%)\end{array}$ & $\begin{array}{c}\text { S3- } \\
\text { Rural } \\
\text { nonfarm } \\
(\%)\end{array}$ & $\begin{array}{l}\text { S4- } \\
\text { Live- } \\
\text { stock }^{\mathrm{a}} \\
(\%)\end{array}$ \\
\hline All sectors (GDP) & 727.4 & $3,045.4$ & 318.7 & 6.15 & 6.47 & 5.54 & 6.26 & 5.46 \\
\hline Agriculture & 253.1 & 499.0 & 97.1 & 2.87 & 2.56 & 3.28 & 2.85 & 3.15 \\
\hline Crops & 177.3 & 306.8 & 73.1 & 2.31 & 1.96 & 2.80 & 2.26 & 2.75 \\
\hline Cereal crops & 81.9 & 148.0 & 80.8 & 2.50 & 2.19 & 2.92 & 2.46 & 2.82 \\
\hline Maize & 13.7 & 27.1 & 98.2 & 2.89 & 2.67 & 3.16 & 2.91 & 3.01 \\
\hline Sorghum & 18.8 & 38.8 & 106.2 & 3.06 & 2.81 & 3.34 & 3.07 & 3.18 \\
\hline Teff & 25.8 & 40.6 & 57.2 & 1.90 & 1.58 & 2.41 & 1.83 & 2.38 \\
\hline Wheat & 15.5 & 25.6 & 65.3 & 2.11 & 1.54 & 2.89 & 1.96 & 2.88 \\
\hline Export crops & 39.7 & 78.0 & 96.4 & 2.85 & 2.40 & 3.47 & 2.78 & 3.49 \\
\hline Coffee & 27.7 & 60.9 & 119.3 & 3.33 & 2.91 & 3.90 & 3.27 & 3.94 \\
\hline Other crops & 55.7 & 80.8 & 45.0 & 1.56 & 1.24 & 2.04 & 1.52 & 2.03 \\
\hline Livestock & 53.2 & 121.9 & 129.2 & 3.52 & 3.26 & 3.88 & 3.54 & 3.42 \\
\hline Other agriculture & 22.7 & 70.3 & 210.2 & 4.83 & 4.64 & 4.97 & 4.86 & 4.98 \\
\hline Industry & 123.1 & 550.3 & 347.2 & 6.44 & 6.89 & 5.32 & 6.62 & 5.18 \\
\hline Mining & 19.4 & 77.6 & 299.1 & 5.94 & 6.63 & 4.47 & 5.80 & 4.43 \\
\hline Manufacturing & 28.7 & 239.1 & 731.9 & 9.23 & 9.62 & 8.23 & 9.48 & 8.06 \\
\hline Agro-processing & 13.7 & 46.7 & 241.5 & 5.25 & 5.30 & 4.95 & 5.24 & 4.78 \\
\hline Other manufacturing & 15.1 & 192.4 & $1,176.3$ & 11.19 & 11.67 & 9.99 & 11.51 & 9.82 \\
\hline Other industry and electricity & 84.2 & 284.4 & 237.7 & 5.20 & 5.63 & 4.13 & 5.39 & 3.99 \\
\hline Construction & 65.5 & 182.9 & 179.2 & 4.37 & 4.82 & 3.14 & 4.61 & 2.97 \\
\hline Services & 351.2 & $1,996.1$ & 468.3 & 7.51 & 7.94 & 6.74 & 7.64 & 6.68 \\
\hline
\end{tabular}

Source: Model simulations.

Note: a. Livestock and crop shift scenario.

b. $2016 / 2017$ birr.

c. Percentage change, 2016/2017-2039/2040. 
TABLE 13.10 Model simulations: Growth of cereal production, prices, and imports, 2016-2040 (\%)

\begin{tabular}{lccccc}
\hline Cereal & $\begin{array}{c}\text { S0- } \\
\text { Baseline }\end{array}$ & $\begin{array}{c}\text { S1- } \\
\text { Cities }\end{array}$ & $\begin{array}{c}\text { S2- } \\
\text { Agriculture }\end{array}$ & $\begin{array}{c}\text { S3- } \\
\text { Rural nonfarm }\end{array}$ & $\begin{array}{c}\text { S4- } \\
\text { Livestock }^{\mathrm{a}}\end{array}$ \\
\hline Maize & & & & & \\
$\quad$ Total factor productivity & 1.68 & 1.36 & 2.11 & 2.11 & 2.11 \\
$\quad$ Production & 2.89 & 2.67 & 3.16 & 2.91 & 3.01 \\
$\quad$ Price & -0.01 & 0.05 & -0.13 & 0.02 & -0.15 \\
Teff & & & & & \\
$\quad$ Total factor productivity & 1.00 & 0.67 & 1.42 & 1.42 & 1.42 \\
Production & 1.90 & 1.58 & 2.41 & 1.83 & 2.38 \\
$\quad$ Price & 1.40 & 1.52 & 1.12 & 1.42 & 1.14 \\
Wheat & & & & & \\
$\quad$ Total factor productivity & 1.46 & 1.13 & 1.88 & 1.88 & 1.88 \\
Production & 2.11 & 1.54 & 2.89 & 1.96 & 2.88 \\
Price & -1.65 & -1.94 & -1.20 & -1.75 & -1.25 \\
Imports & 6.40 & 6.66 & 5.80 & 6.38 & 5.62 \\
Imports/availability & 20.8 & 24.2 & 16.1 & 21.4 & 15.5 \\
\hline
\end{tabular}

Source: Model simulations.

Note: a. Livestock and crop shift scenario.

(2.11 percent) and maize (2.89 percent) are thus significantly higher than for teff (1.90 percent) (Table 13.10). For teff, steady income growth raises demand faster than the increases in supply, so prices rise steadily by 1.40 percent per year. Demand for maize increases at the same rate as supply, so maize prices are essentially unchanged over time. For wheat, however, increases in demand lead to an increase in imports, which rise by 6.4 percent per year. By 2040 wheat imports account for 20.8 percent of supply. In the Cities simulation (S1), with higher public investment in cities but lower agricultural investment, growth in TFP and production of all three major cereal crops is lower and prices are higher, except for wheat, for which imports increase. Agricultural production growth rates are highest and wheat imports are lowest in the scenarios involving more agricultural investment (S2 and S4).

In the base run, as well as in the other scenarios, the share of agriculture in GDP falls over time (from more than 40 percent in 2010 to under 10 percent in 2040 in the base run). The share of the broader agriculture and food system (AFS) also declines over time. However, the share of downstream activities (processing, trade, and transport costs) in total AFS GDP increases steadily, from about 20 percent in 2010 to more than 30 percent in 2040, as a result of 
FIGURE 13.7 Baseline agrifood system dynamics in Ethiopia, 2015/2016-2039/2040

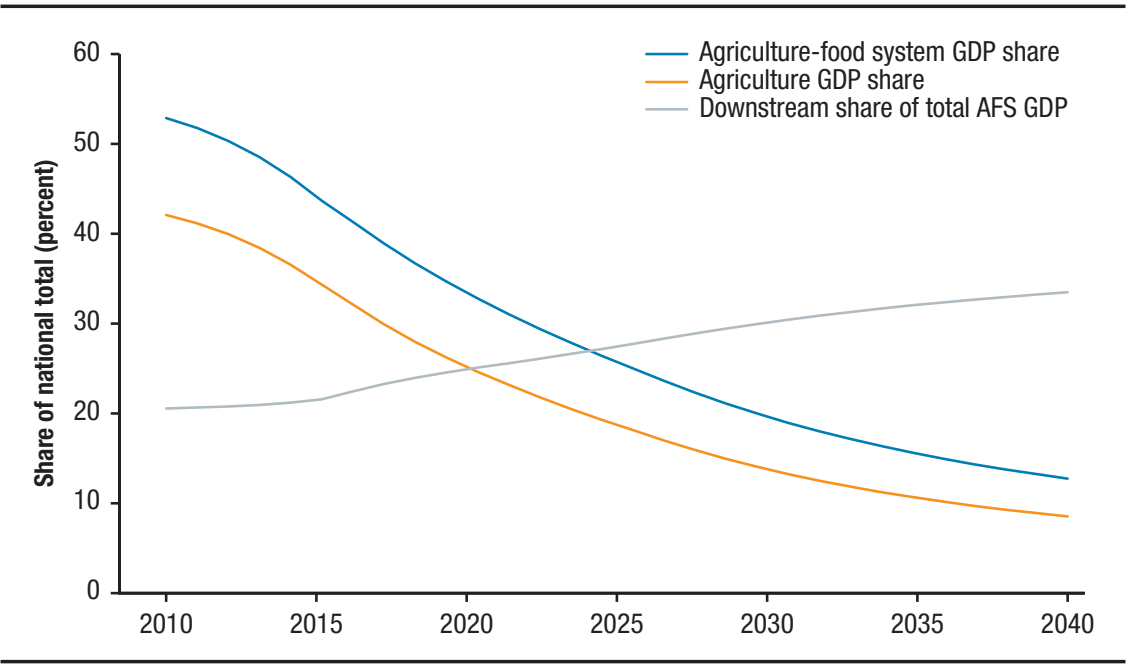

Source: Model simulations.

TABLE 13.11 Agrifood system outcomes in Ethiopia, annual average growth rates, 2015/2016-2039/2040 (\%)

\begin{tabular}{lccccc}
\hline Sector & $\begin{array}{c}\text { S0- } \\
\text { Baseline }\end{array}$ & $\begin{array}{c}\text { S1- } \\
\text { Cities }\end{array}$ & $\begin{array}{c}\text { S2- } \\
\text { Agriculture }\end{array}$ & $\begin{array}{c}\text { S3- } \\
\text { Rural nonfarm }\end{array}$ & $\begin{array}{c}\text { S4- } \\
\text { Livestock }^{\text {a }}\end{array}$ \\
\hline National economy & 6.1 & 6.5 & 5.5 & 6.3 & 5.5 \\
Agriculture-food system & 3.3 & 3.1 & 3.6 & 3.3 & 3.4 \\
Agriculture & 2.9 & 2.6 & 3.3 & 2.8 & 3.1 \\
Agro-processing & 5.3 & 5.3 & 4.9 & 5.2 & 4.8 \\
Input production & 4.8 & 4.7 & 4.8 & 4.9 & 4.5 \\
Trade and transport services & 4.3 & 4.2 & 4.3 & 4.2 & 4.2 \\
\hline
\end{tabular}

Source: Model simulations.

Note: a. Livestock and crop shift scenario.

sharp increases in marketed sales, urban demand, and overall demand for processed products (Figure 13.7 and Table 13.11).

Table 13.12 presents simulation results for per capita expenditure growth by household group and population growth. Overall, per capita household incomes increase by 2.35 percent per year overall (2.60 percent per year in rural areas and 1.30 percent per year in urban areas). Slower per capita income growth in urban areas is due in part to rural-urban migration that contributes to a faster population growth rate in urban areas ( 3.30 percent per year) than in rural areas (1.70 percent per year). Within rural areas, faster agricultural 
TABLE 13.12 Model simulations: Per capita expenditure growth in Ethiopia, 2016-2040 (\%)

\begin{tabular}{|c|c|c|c|c|c|c|c|c|c|c|}
\hline \multirow[b]{2}{*}{ Indicator } & \multicolumn{5}{|c|}{ All Households } & \multicolumn{5}{|c|}{ Poorest $40 \%$} \\
\hline & $\begin{array}{c}\text { S0- } \\
\text { Base- } \\
\text { line }\end{array}$ & $\begin{array}{l}\text { S1- } \\
\text { Cities }\end{array}$ & $\begin{array}{l}\text { S2- } \\
\text { Agricul- } \\
\text { ture }\end{array}$ & $\begin{array}{l}\text { S3- } \\
\text { Rural } \\
\text { non- } \\
\text { farm }\end{array}$ & $\begin{array}{l}\text { S4- } \\
\text { Live- } \\
\text { stock }^{\text {a }}\end{array}$ & $\begin{array}{l}\text { S0- } \\
\text { Base- } \\
\text { line }\end{array}$ & $\begin{array}{l}\text { S1- } \\
\text { Cities }\end{array}$ & $\begin{array}{l}\text { S2- } \\
\text { Agricul- } \\
\text { ture }\end{array}$ & $\begin{array}{l}\text { S3- } \\
\text { Rural } \\
\text { non- } \\
\text { farm }\end{array}$ & $\begin{array}{l}\text { S4- } \\
\text { Live- } \\
\text { stock }^{\text {a }}\end{array}$ \\
\hline Rural & 2.60 & 2.54 & 2.62 & 2.80 & 2.51 & 3.79 & 3.79 & 3.64 & 3.98 & 3.56 \\
\hline R1: Dry highlands & 2.54 & 2.48 & 2.52 & 2.73 & 2.42 & 3.51 & 3.53 & 3.30 & 3.71 & 3.25 \\
\hline R2: Dry lowlands & 1.89 & 1.67 & 2.22 & 2.14 & 2.14 & 2.99 & 2.82 & 3.17 & 3.19 & 3.18 \\
\hline R3: Moist lowlands & 2.13 & 1.98 & 2.46 & 2.43 & 2.55 & 3.42 & 3.36 & 3.63 & 3.68 & 3.95 \\
\hline $\begin{array}{l}\text { R4: Moist high } \\
\text { cereals }\end{array}$ & 2.97 & 2.98 & 2.85 & 3.14 & 2.70 & 4.24 & 4.30 & 3.98 & 4.42 & 3.81 \\
\hline $\begin{array}{l}\text { R5: Moist high- } \\
\text { enset }\end{array}$ & 2.52 & 2.46 & 2.54 & 2.76 & 2.46 & 3.56 & 3.51 & 3.48 & 3.74 & 3.41 \\
\hline Urban & 1.30 & 1.37 & 1.11 & 0.98 & 0.97 & 0.73 & 0.78 & 0.52 & 0.46 & 0.38 \\
\hline National & 2.35 & 2.33 & 2.30 & 2.40 & 2.19 & 3.28 & 3.28 & 3.12 & 3.41 & 3.03 \\
\hline $\begin{array}{l}\text { Rural population } \\
\text { growth }\end{array}$ & 1.70 & 1.70 & 1.71 & 1.71 & 1.71 & 2.19 & 2.19 & 2.20 & 2.20 & 2.20 \\
\hline $\begin{array}{l}\text { Urban population } \\
\text { growth }\end{array}$ & 3.30 & 3.32 & 3.29 & 3.27 & 3.29 & 4.47 & 4.48 & 4.44 & 4.43 & 4.44 \\
\hline $\begin{array}{l}\text { Total population } \\
\text { growth }\end{array}$ & 2.04 & 2.04 & 2.04 & 2.04 & 2.04 & 2.58 & 2.58 & 2.58 & 2.58 & 2.58 \\
\hline
\end{tabular}

Source: Model simulations.

Note: a. Livestock and crop shift scenario.

productivity growth in the highlands contributes to more rapid per capita income growth in the highland regions than in the lowlands. Incomes of poor households (the bottom 40 percent of the income distribution) increase slightly faster at 3.28 percent per year overall, but at 3.79 percent per year for the rural poor. Incomes of poor urban households increase at only 0.73 percent per year.

\section{Policy Scenarios: The Implications of Alternative Public Investment Strategies}

Simulations of alternative public investment strategies using an economywide model of the Ethiopian economy highlight the trade-offs between various policy options. Investments in urban infrastructure result in the highest growth rate of an average of 6.47 percent per year from 2017 through 2040. Agricultural sector investments, whether in crops or livestock, result in lower growth rates of 5.54 percent and 5.46 percent per year, respectively. In part, this is due to lower productivity of agricultural investments as well as to 
FIGURE 13.8 Model simulations: Growth outcomes in Ethiopia by total, rural, urban, agricultural, and nonagricultural GDP, 2015/2016-2039/2040

Deviation from baseline, 2040 (percent)

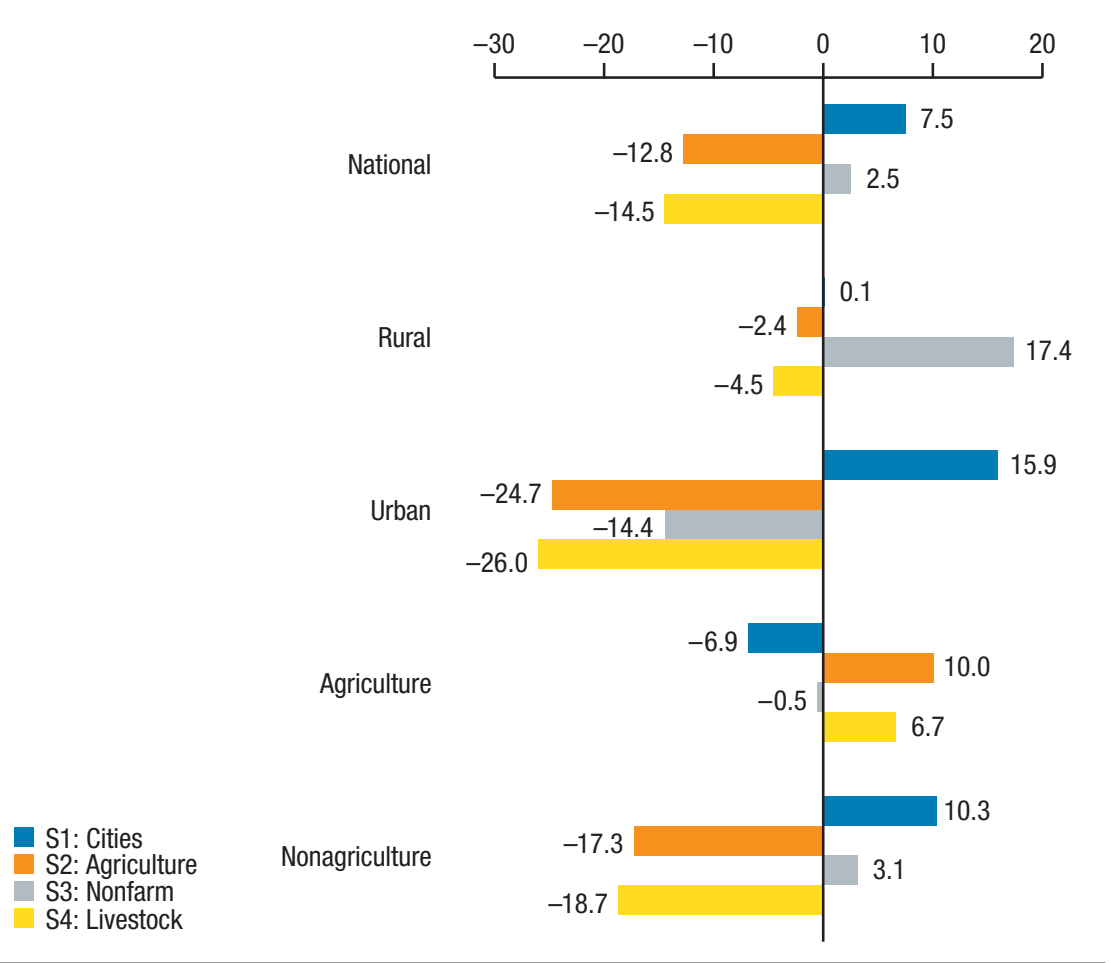

Source: Model simulations.

Note: S4 = the livestock and crop shift scenario.

increases in overall investment, as the simulations assume that total investment as a share of GDP is constant across simulations. Thus greater increases in GDP in the urban investment scenario not only generates more consumption, they also result in increased investment and more future growth. By 2040 real GDP in the urban investment scenario is 7.5 percent higher than in the baseline simulation, and real GDP in the agricultural investment scenarios is 12.8 percent lower.

Not surprisingly, the largest gains in agricultural GDP arise from investments in crop agriculture (S2) or the livestock and crop shift (S4) scenarios, with GDP levels in these scenarios that are 10.0 percent and 6.7 percent greater than in the baseline, respectively, by 2040 (Figure 13.8). However, because these investments draw resources away from rural nonagriculture 
activities, overall rural GDP is actually somewhat lower than in the baseline at -2.4 percent and -4.5 percent in crop and livestock investment simulations, respectively. Real nonagricultural GDP is also 17.3 percent and 18.7 percent lower in 2040 than in the baseline in the increased crop and livestock investment scenarios. The biggest gains in overall rural GDP, however, arise from investments in the rural nonfarm sector-rural GDP is 17.4 percent higher under this scenario relative to the baseline. By contrast, increased public investment in urban sectors, because it crowds out public investment in rural sectors, results in a decline in agricultural GDP by 6.9 percent in 2040 .

National welfare improves in all scenarios, including the baseline and, in general, rural welfare increases faster than urban welfare, although from a lower initial level. Overall, the urban economy grows faster in all scenarios, but increased rural-urban migration in the urban investment scenario dampens urban per capita income growth. Faster urban growth in the urban investment scenario widens the rural-urban income divide; greater rural investment in agriculture and small-town scenarios narrows the rural-urban divide.

Household welfare outcomes differ considerably across scenarios, however. Investments in agriculture lead to similar changes in national household consumption in 2040 as do investments in cities. The largest gains in national welfare come from investments in the rural nonfarm sector. Although a shift toward urban investments benefits urban households by 1.5 percentage points relative to the baseline, national average welfare falls by 0.7 percentage points relative to the baseline (Figure 13.9). In part, this is because gains in incomes of urban households lead to greater demand for imported products, including imported agricultural products. In contrast, rural households who gain from higher rural nonfarm incomes generally spend a higher share of their incomes on local nonagricultural goods and services, spurring rural incomes. ${ }^{18}$

Given the concentration of poverty in rural areas and linkages between agriculture and small towns, investments in agriculture and rural nonfarm are more pro-poor than investments in cities. In fact, rural nonfarm investment is more pro-poor than both agricultural investments and investments

18 Analysis by Diao et al. (2007) showed that rural households spend about 0.60 birr for each additional birr of income on nonagricultural commodities and that low-income rural households have a higher marginal budget share (MBS) of nonagricultural spending compared to high-income groups. In rural areas the MBS of nonagricultural products and services for lowest income quintiles is about 0.74 compared with 0.47 for the top income quintile, indicating that additional income for the lowest income groups will stimulate demand for nonfarm products and other urban-based products and services and thereby spur economywide growth. Given a large market size in rural areas, investment in nonfarm activities would generate large welfare gains due to strong income and demand linkages. 
FIGURE 13.9 Model simulations: Annual per capita consumption growth in Ethiopia, 2015/2016-2039/2040

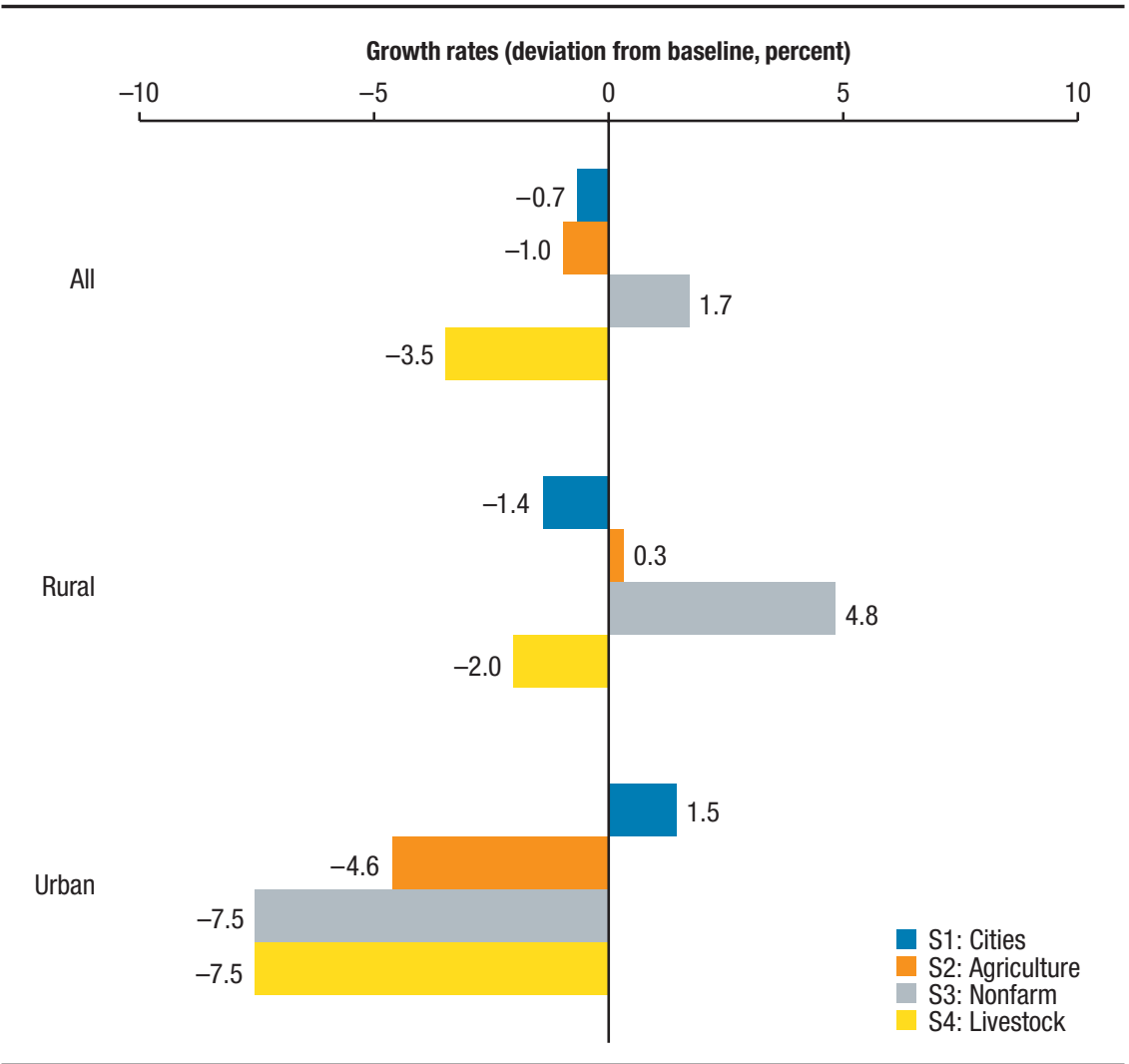

Source: Model simulations.

Note: $\mathrm{S} 4$ = the livestock and crop shift scenario.

in cities. This is because rural nonfarm investments result in large gains in incomes in 2040 to poor households (2.5 percent) as well as nonpoor households (1.4 percent) (Figure 13.10). Investments in cities draw resources away from the agrifood system, which hurts both poor and nonpoor consumers. Note that households in small towns mainly consume agricultural commodities, products of agro-processing, and services. In particular, poor households in both small and large urban centers spend a higher share of their income on agricultural commodities as compared to nonpoor households (Ferede and File 2018). This strong demand stimulus is expected to spur increased output and productivity of rural nonfarm activities, which would benefit mainly poor households in rural and small towns. 
FIGURE 13.10 Model simulations: Annual per capita consumption growth for poor and nonpoor households in Ethiopia, 2015/2016-2039/2040

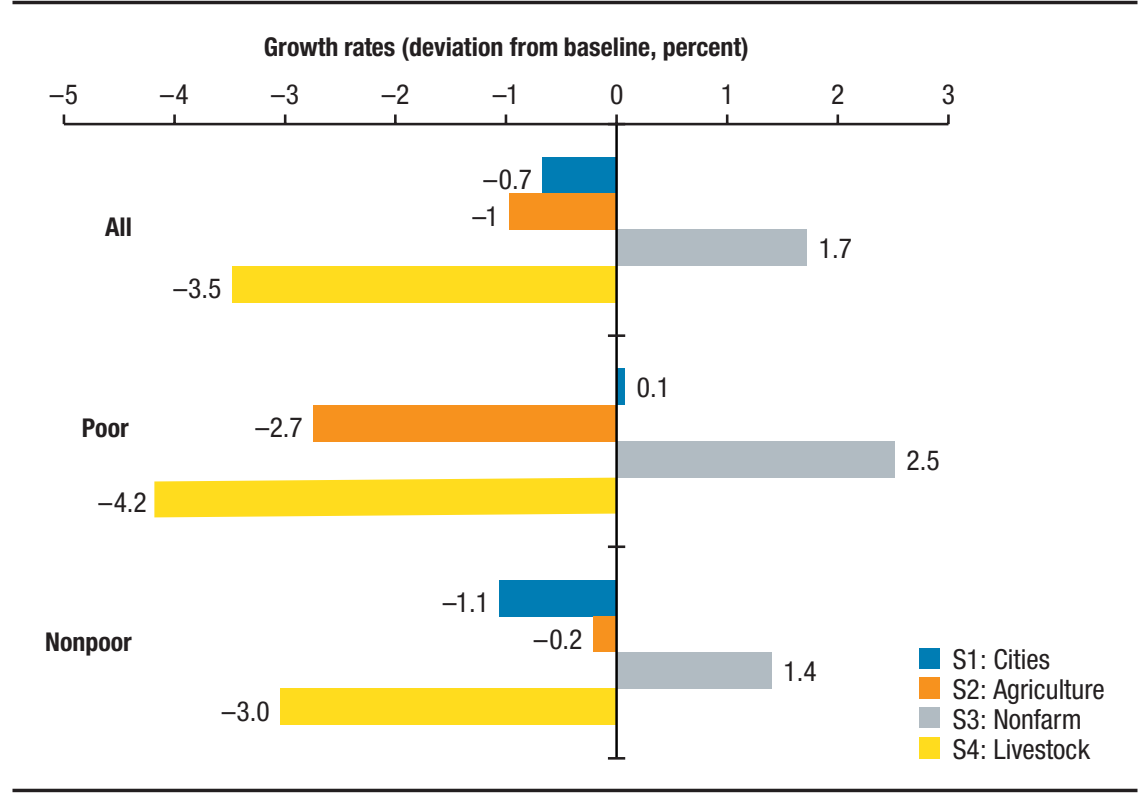

Source: Model simulations.

Note: $\mathrm{S} 4$ = the livestock and crop shift scenario. Poor households = those in the lowest 40 percent of the income distribution.

The above estimates of poverty impacts, however, measure the overall impacts of a consistent investment policy over more than 20 years, a period in which the economy becomes increasingly urban and the share of agriculture in GDP and employment declines steadily. Considering only the marginal impact of each year's public investments on poverty in the four policy scenarios shows that at some point urban investments dominate in terms of both growth and poverty outcomes (Figure 13.11).

The model simulations suggest that the poverty reducing effects of investments in agriculture may diminish as the structure of the economy changes. Thus, while investments in agriculture lead to a 0.8 percent greater reduction in poverty than urban investments in 2017 , by 2025 investments in cities will have a greater effect on poverty. Likewise, investments in the rural nonfarm sector have a larger impact on poverty than investments in cities only through 2026; afterward, investments in cities dominate in terms of both growth and equity. Moreover, as indicated in Figure 13.10, which reflects the cumulative impact of these alternative investments as reflected in the average annual 
FIGURE 13.11 Annual per capita consumption growth for poor households in Ethiopia

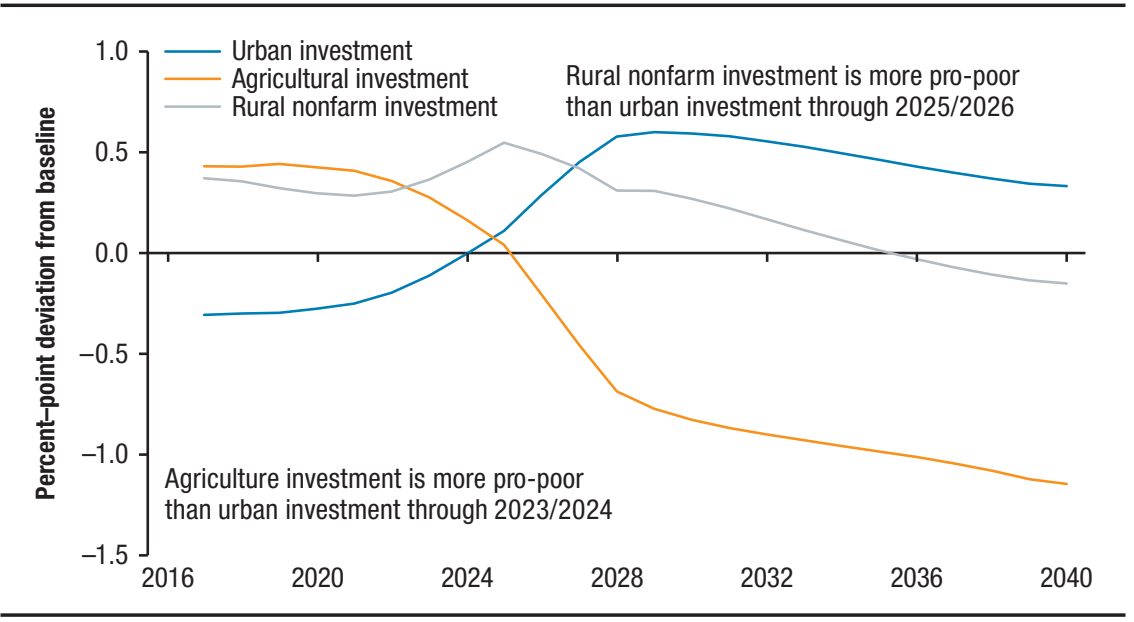

Source: Model simulations.

Note: Poor households $=$ those in the lowest 40 percent in the income distribution.

growth rates from 2016/2017 to 2039/2040, investments in cities modeled in Simulation 1 ultimately results in higher income growth for both the overall economy and the poor. This suggests that an optimal strategy for growth and equity may involve continued high rates of public investment in agriculture and the rural nonfarm sectors through the mid-2020s with a shift toward investments in cities thereafter.

\section{Sensitivity Analysis: Poverty Impacts of Alternative Investments}

This analysis of the changes in the impacts of public investments on poverty over time suggests that these impacts depend significantly on the structure of the economy and the relative pace of agricultural and nonagricultural growth. To quantify these effects, we conduct sensitivity analysis assuming higher foreign savings and three alternative sets of agricultural and nonagricultural TFP growth rates (see Appendix 13C for a description of the alternative baseline simulations).

As shown in Figure 13.12, speeding up nonag TFP growth from 0.50 in period 1 (2016-2027) and in both periods 1 and 2 (2016-2040) has little effect on the relative impacts of agricultural, rural nonfarm, and investments in cities in the initial years of the simulation, but the effects increase over time. In all cases, agricultural growth is more pro-poor than urban growth from 2017 through 2023. Increased foreign savings and faster growth in nonagricultural TFP result in a gradual increase in the impact of agricultural growth 
FIGURE 13.12 Relative effects of sectoral investments on incomes of the rural poor in Ethiopia, 2017-2040: Sensitivity analysis

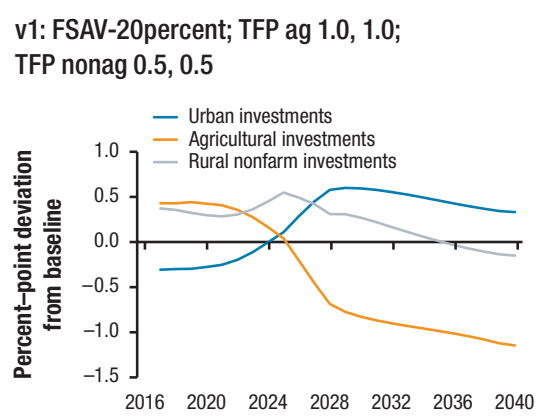

v3: FSAV-15percent; TFP ag 1.0, 1.0; TFP nonag 1.0, 1.0

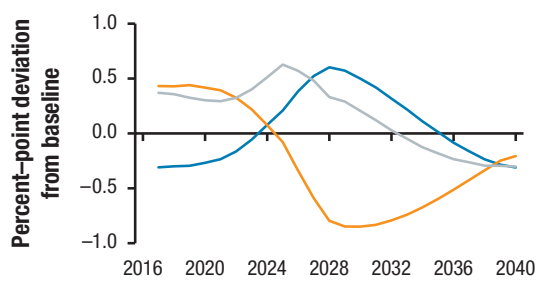

v2: FSAV-15percent; TFP ag 1.0, 1.0;

TFP nonag 1.0, 0.5

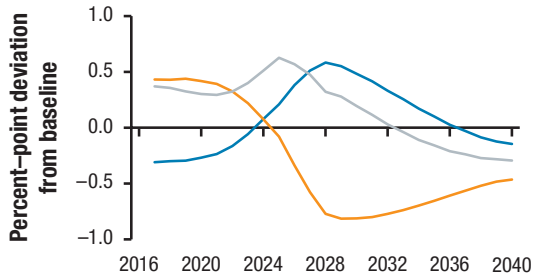

v4: FSAV-15percent; TFP ag 0.5, 0.5;

TFP nonag 1.0, 1.0

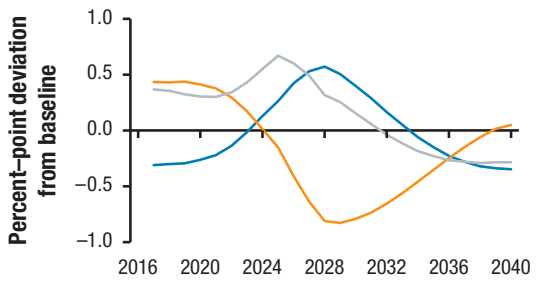

Source: Model simulations.

on incomes of the rural poor relative to the baseline, as a larger nonagricultural sector provides a bigger market and higher sales prices for agricultural products. ${ }^{19}$ Whereas in version $1(\mathrm{vl})$ of the simulations, the gap between the income effect of agricultural investments relative to the baseline gap widens over time, in $\mathrm{v} 2$ and $\mathrm{v} 3$, the gap narrows after 2028. With fast TFP growth in nonagricultural sectors for the entire 2017-2040 period (v3), incomes of the rural poor are actually greater after 2039 with agricultural investments than with alternative investments. Under a slow trend agricultural TFP growth scenario ( $\mathrm{v} 4)$, marginal increases in agricultural investments lead to higher incomes of the rural poor from 2037.

These results suggest that the dominance of agricultural investments relative to nonagricultural investments for raising incomes of the poor hold through about 2024 even under alternative assumptions regarding growth

19 Note that foreign savings, though higher than in the main simulations, still declines sharply over time. 
rates of total factor productivity in the nonagricultural and agricultural sectors. Structural change in the Ethiopian economy is likely to diminish the relative dominance of agriculture for reducing poverty over the next ten years, but in the shorter run of, say, five years, agricultural sector investments appear to be the most pro-poor.

\section{Conclusion}

Several broad conclusions emerge from this analysis. First, agricultural grow th is likely to decelerate as land constraints become increasingly binding, especially in the highlands. Given that the rural population is projected to increase despite continued urbanization, average farm size will likely increase. Continued investments in research and technology—for example, continued improvement and dissemination of high-yielding varieties and increased supply of fertilizer-to increase agricultural productivity will be crucial to avoid a large increase in imports or declining food availability. Increased supplies of fertilizer, both in quantity and quality (composition), targeted to specific crops and localities will also be needed, along with significant levels of public investment in irrigation and rural infrastructure-for example, rural road networks through the universal rural road access program. Second, rapid growth in the nonfarm economy will likely result in a sharp increase in market demand for agricultural products (see Chapter 7). Increases in agricultural production (see Chapter 3) will be needed to avoid major increases in imports or a sharp increase in real food prices that would harm the poor. Facilitating the expansion of this broader agrifood system through well-designed policies and public and private investments will be crucial to meet the growing market demand.

Third, economywide analysis suggests that investments in cities generate faster economic growth and structural transformation but that, given the large share of the population with incomes linked to agriculture and the rural economy, investments in the rural economy are likely to continue to be more pro-poor than public investments in cities through the mid-2020s (see Chapter 12). Further work is needed on understanding the dynamics of the agrifood system, including the effects of changing household demand behavior, especially the shift from own-consumption to marketed output. Other priority areas for research include the implications for productivity growth and income distribution of changes in technology—for example, expansion of solar and other non-fossil-fuel energy, increases in use and further advances in information/digital technology, and so on. 
In summary, even with rapid urbanization most of Ethiopia's population, as well as the poor in the bottom two income quintiles, will likely still live in rural areas and small towns in 2040, where agricultural production, processing, and trade remain the main livelihoods, especially for the poor. Though rapid economic growth and structural transformation have diminished the relative importance of the agricultural sector in Ethiopia's economy, continued public investments in agriculture and the broader agrifood system will remain crucial for equity and poverty alleviation in Ethiopia.

\section{Appendix 13A: Accounts in the 2015/2016 Ethiopia NEXUS Social Accounting Matrix}

\section{Activities/Commodities (45 Sectors)}

\section{AGRICULTURE (23)}

- Crops (15): maize, sorghum, teff, barley, wheat, pulses, oils, roots, vegetables, sugar cane, tobacco, fruit;

- Livestock and other primary sectors (8): cattle, milk, poultry, sheep and goats, other livestock, forestry, fish, mining.

INDUSTRY (16)

- Meat processing, dairy, grain milling, sugar refining, other food processing, beverages, textiles, leather, wood, chemicals, metals, machinery, other manufacturing, electricity, water, construction.

\section{SERVICES (6)}

- Trade, transport, financial services, real estate, government services, other services.

FACTORS OF PRODUCTION (47)

- Labor (18): three skill levels (no education, primary, secondary) in six regions;

- Land (5): in five rural regions;

- Capital (24): four types of capital (crops, livestock, mining, nonagriculture) in six regions. 


\section{INSTITUTIONS (38)}

- Households (30): five quintiles in six regions;

- Other institutions (8): enterprises (in six regions); government, rest of world.

\section{REGIONS (6)}

- R1 Drought prone highlands

- R2 Moisture reliable highland cereal

- R3 Moisture reliable highland enset

- R4 Moisture reliable lowland

- R5 Drought prone lowland and pastoralist

- U1 Urban

\section{Appendix 13B: Assumptions in Growth Projections}

TABLE 13B.1 Assumed annual growth rates of land and livestock capital in Ethiopia, by rural region and scenario (\%)

\begin{tabular}{|c|c|c|c|c|c|c|}
\hline & Base & Base & $\begin{array}{l}\text { S1, S2, } \\
\text { and S3 }\end{array}$ & $\begin{array}{l}\mathrm{S} 1, \mathrm{~S} 2 \text {, } \\
\text { and S3 }\end{array}$ & S4 & S4 \\
\hline Category & 2017-2027 & 2027-2040 & 2017-2027 & 2027-2040 & 2017-2027 & 2027-2040 \\
\hline Land & 0.40 & 0.00 & 0.40 & 0.00 & 0.30 & -0.10 \\
\hline R1: Dry highlands & 1.00 & 0.80 & 1.00 & 0.80 & 1.10 & 0.90 \\
\hline R2: Dry lowlands & 2.00 & 1.50 & 2.00 & 1.50 & 2.10 & 1.60 \\
\hline R3: Moist lowlands & 1.00 & 0.50 & 1.00 & 0.50 & 0.90 & 0.40 \\
\hline R4: Moist high cereals & 0.50 & 0.00 & 0.50 & 0.00 & 0.40 & -0.10 \\
\hline R5: Moist high enset & 0.00 & 0.00 & 0.00 & 0.00 & 0.00 & 0.00 \\
\hline \multicolumn{7}{|l|}{ Livestock } \\
\hline R1: Dry highlands & 0.40 & 0.00 & 0.40 & 0.00 & 1.40 & 1.00 \\
\hline R2: Dry lowlands & 1.00 & 0.80 & 1.00 & 0.80 & 0.00 & -0.20 \\
\hline R3: Moist lowlands & 2.00 & 1.50 & 2.00 & 1.50 & 1.00 & 0.50 \\
\hline R4: Moist high cereals & 1.00 & 0.50 & 1.00 & 0.50 & 2.00 & 1.50 \\
\hline R5: Moist high enset & 0.50 & 0.00 & 0.50 & 0.00 & 1.50 & 1.00 \\
\hline
\end{tabular}

Source: Model simulations. 
TABLE 13B.2 Assumed annual growth rates in total factor productivity in Ethiopia, by scenario, subsector, and analytical period (\%)

\begin{tabular}{|c|c|c|c|c|c|}
\hline Sector & Base & $\begin{array}{l}\text { S1: } \\
\text { Cities }\end{array}$ & $\begin{array}{c}\text { S2: } \\
\text { Agriculture }\end{array}$ & $\begin{array}{c}\text { S3: } \\
\text { Rural } \\
\text { nonfarm }\end{array}$ & $\begin{array}{c}\text { S4: } \\
\text { Livestock }\end{array}$ \\
\hline \multicolumn{6}{|l|}{ Agriculture } \\
\hline 2017-2027 & 2.50 & 1.79 & 3.43 & 2.50 & 3.43 \\
\hline $2027-2040$ & 1.00 & 1.00 & 1.00 & 1.00 & 1.00 \\
\hline \multicolumn{6}{|c|}{ Crops (all regions) } \\
\hline $2017-2027$ & 2.50 & 1.79 & 3.43 & 2.50 & 3.43 \\
\hline $2027-2040$ & 1.00 & 1.00 & 1.00 & 1.00 & 1.00 \\
\hline \multicolumn{6}{|c|}{ Livestock (regions R1, R4, and R5) } \\
\hline 2017-2027 & 1.00 & 0.29 & 1.93 & 1.00 & 0.93 \\
\hline $2027-2040$ & 1.00 & 1.00 & 1.00 & 1.00 & 0.00 \\
\hline \multicolumn{6}{|c|}{ Livestock (regions R2 and R3) } \\
\hline 2017-2027 & 1.00 & 0.29 & 1.93 & 1.00 & 2.93 \\
\hline $2027-2040$ & 1.00 & 1.00 & 1.00 & 1.00 & 2.00 \\
\hline \multicolumn{6}{|c|}{ Nonagriculture (all regions) ${ }^{*}$} \\
\hline $2017-2027$ & 0.50 & 0.50 & 0.50 & 1.43 & 0.50 \\
\hline $2027-2040$ & 0.50 & 0.50 & 0.50 & 0.50 & 0.50 \\
\hline
\end{tabular}

Source: Model simulations.

Note: $\mathrm{S} 4$ = the livestock and crop shift scenario. * Nonagriculture includes urban regions.

\section{Appendix 13C: Alternative Base Simulations}

Several alternative base simulations were constructed as part of the sensitivity analysis of poverty impacts (Table 13C.1). Base 1 is the main base simulation used in the analysis in which agricultural TFP grows by 1.0 percent per year and nonagricultural TFP grows by 0.5 percent for the entire 2015-2040 period. Given that foreign borrowing was unsustainably high in the 20112016 period, we model a sharp reduction in foreign savings over time, reducing foreign savings by 20 percent per year from 2016 through 2027 and by 10 percent per year from 2028 through 2040.

In this base simulation, nonagricultural GDP increases much faster (7.25 percent per year) than does agricultural GDP (2.87 percent per year), and total GDP increases by 6.15 percent per year. Given the still substantial inflow of foreign savings in the economy, the real exchange rate appreciates by an average of 1.75 percent per year, reducing incentives for exports. Prices of wheat, a major importable good, and coffee, a major exportable 
TABLE 13C.1 Alternative base simulation assumptions and resultant key average annual growth rates in Ethiopia, 2014-2040 (\%)

\begin{tabular}{|c|c|c|c|c|c|}
\hline Model variable & Base 1 & Base 1a & Base 2 & Base 3 & Base 4 \\
\hline \multicolumn{6}{|c|}{ Assumptions (annual growth rates) } \\
\hline \multicolumn{6}{|l|}{ Foreign savings } \\
\hline $2016-2027$ & -20.00 & -15.00 & -15.00 & -15.00 & -15.00 \\
\hline 2028-2040 & -10.00 & -10.00 & -10.00 & -10.00 & -10.00 \\
\hline \multicolumn{6}{|c|}{ Agricultural total factor productivity } \\
\hline $2016-2027$ & 1.00 & 1.00 & 1.00 & 1.00 & 0.50 \\
\hline 2028-2040 & 1.00 & 1.00 & 1.00 & 1.00 & 0.50 \\
\hline \multicolumn{6}{|c|}{ Nonagricultural total factor productivity } \\
\hline 2016-2027 & 0.50 & 0.50 & 1.00 & 1.00 & 1.00 \\
\hline 2028-2040 & 0.50 & 0.50 & 0.50 & 1.00 & 1.00 \\
\hline \multicolumn{6}{|c|}{ Scenario results (annual growth rates) } \\
\hline Total GDP & 6.15 & 6.51 & 7.07 & 7.47 & 7.25 \\
\hline Agricultural GDP & 2.87 & 2.87 & 2.86 & 2.86 & 2.22 \\
\hline Nonagricultural GDP & 7.25 & 7.69 & 8.35 & 8.82 & 8.65 \\
\hline Real exchange rate & -1.75 & -1.97 & -2.28 & -2.48 & -2.61 \\
\hline Wage (R2 unskilled) & 1.87 & 1.95 & 2.06 & 2.13 & 1.66 \\
\hline Per capita income rural poor & 2.99 & 3.19 & 3.48 & 3.67 & 3.22 \\
\hline Agricultural prices & -0.14 & -0.16 & -0.18 & -0.20 & -0.03 \\
\hline Maize & -0.01 & 0.03 & 0.09 & 0.13 & 0.42 \\
\hline Wheat & -1.65 & -1.82 & -2.07 & -2.24 & -2.33 \\
\hline Teff & 1.40 & 1.47 & 1.56 & 1.61 & 1.63 \\
\hline Coffee & -0.99 & -1.07 & -1.16 & -1.21 & -0.78 \\
\hline Cattle & 0.39 & 0.48 & 0.58 & 0.63 & 0.69 \\
\hline
\end{tabular}

Source: Model simulations.

good, decline over time by 1.65 percent and 0.99 percent per year, respectively. However, given the rapid economic growth, the wage rate for rural unskilled labor increases by 1.87 percent per year and per capita incomes of the rural poor (the bottom 40 percent in the per capita expenditure distribution) rise by 2.99 percent per year.

In Base 1a, increasing the foreign savings inflow by reducing the rate of decline of foreign savings from -20 percent per year to -15 percent per year in the 2016-2027 period results in faster GDP growth (6.51 percent per year in Base 1a versus 6.15 percent per year in Base 1), as the increased foreign savings funds faster investment growth. The real exchange rate appreciates more 
rapidly, contributing to greater declines in wheat and coffee prices, but annual growth in wage rates for rural unskilled labor and per capita incomes of the rural poor accelerate slightly, by 0.08 and 0.20 percentage points, respectively.

Increasing the growth rate of nonagricultural TFP from 0.50 in period 1 (2016-2027) and in both periods 1 and 2 (2016-2040), results in further increases in GDP and nonagricultural GDP growth rates but has little effect on agricultural GDP growth rates (Base 2 and Base 3). Nonetheless, faster nonagricultural GDP productivity growth results in larger gains in rural wage rates for unskilled labor and per capita incomes of the rural poor relative to Base 1 and 1a.

Finally, a reduction in the growth rate of agricultural TFP from 1.0 percent per year to 0.5 percent per year (Base 4 ) leads to a sharp slowdown in agricultural GDP growth (from 2.86 percent to 2.22 percent per year in Base 3). Nonagricultural GDP growth also slows due to a reduction in demand for nonagricultural goods and services. The annual growth rates of the wage rate of unskilled rural labor and of per capita incomes of the rural poor fall steeply by 0.47 and 0.45 percentage points relative to Base 3 , respectively. Lower productivity growth in agriculture also results in higher agricultural prices-an increase in the annual growth rate of average prices of five major agricultural commodities by 0.17 percentage points.

\section{References}

Armington, P. A. 1969. "A Theory of Demand for Products Distinguished by Place of Production." IMF Staff Papers 16 (1): 159-178.

Bachewe, F., G. Berhane, B. Minten, and A. S. Taffesse. 2018. "Agricultural Transformation in Africa? Assessing the Evidence in Ethiopia." World Development 105 (c): 286-298.

Benin, S., S. Fan, and M. Johnson. 2012. Estimating Public Agricultural Expenditure Requirements. Washington, DC: International Food Policy Research Institute (IFPRI).

Dervis K., J. de Melo, and S. Robinson. 1982. General Equilibrium Models for Development Policy. New York: Cambridge University Press.

Diao, X., B. Fekadu, S. Haggblade, A. S. Taffesse, K. Wamisho, and B. Yu. 2007. Agricultural Growth Linkages in Ethiopia: Estimates Using Fixed and Flexible Price Models. IFPRI Discussion Paper 695. Washington, DC: IFPRI.

Diao, X., A. S. Taffesse, P. Dorosh, J. Thurlow, A. N. Pratt, and B. Yu. 2013. “Ethiopia.” In Strategies and Priorities for African Agriculture: Economywide Perspectives from Country Studies, edited by X. Diao, J. Thurlow, S. Benin, and S. Fan, 107-139. Washington, DC: IFPRI. 
Diao, X., and J. Thurlow. 2013. “A Recursive Dynamic Computable General Equilibrium Model.” In Strategies and Priorities for African Agriculture: Economywide Perspectives from Country Studies, edited by X. Diao, J. Thurlow, S. Benin, and S. Fan, 17-50. Washington, DC: IFPRI.

Dimaranan, B. 2006. Global Trade, Assistance and Production: The GTAP 6 Data Base. West Lafayette, IN, US: Center for Global Trade Analysis, Purdue University.

Dorosh, P., and J. Thurlow. 2012. "Agglomeration, Growth and Regional Equity: An Analysis of Agriculture- versus Urban-led Development in Uganda." Journal of African Economies 21 (1): 94-123.

— . 2013a. "Agriculture and Small Towns in Africa." Agricultural Economics 44 (3): 435-445. 2013b. "Implications of Accelerated Agricultural Growth on Household Incomes and Poverty in Ethiopia: A General Equilibrium Analysis." In Food and Agriculture in Ethiopia: Progress and Policy Challenges, edited by P. Dorosh and S. Rashid, 219-255. Philadelphia: University of Pennsylvania Press.

- 2014. "Can Cities or Towns Drive African Development? Economywide Analysis for Ethiopia and Uganda." World Development 63: 113-123.

Dorosh, P., J. Thurlow, F. Worku-Kebede, T. Ferede, and A.S. Taffesse. 2018. Structural Change and Poverty Reduction in Ethiopia: Economy-wide Analysis of the Evolving Role of Agriculture. Working Paper 123 (September). Addis Ababa: IFPRI Ethiopia Strategy Support Program.

EPAU (Economic and Policy Analysis Unit) and IFPRI (International Food Policy Research Institute). 2017. 2010/11 Social Accounting Matrix for Ethiopia. Washington, DC: IFPRI.

Ethiopia. 2011. Ethiopia’s Climate-Resilient Green Economy: Green Economy Strategy. Federal Democratic Republic of Ethiopia, Addis Ababa.

Ethiopia, CSA (Central Statistical Agency). 2012. Household Income, Consumption and Expenditure Survey 2010/11. Addis Ababa.

-2013. Population Projections for Ethiopia 2007-2037. Addis Ababa.

- Various years. Report on Area and Production of Major Crops. Addis Ababa.

Ethiopia, MoFED (Ministry of Finance and Economic Development). Various years. Unpublished data, Addis Ababa.

Ferede, T., and B. File. 2019. "Rural-Urban Linkages in Ethiopia." In Oxford Handbook of the Ethiopian Economy, edited by Fantu C., C. Cramer, and A. Oqubay, 763-784. New York: Oxford University Press.

Henderson, J. V., and H. G. Wang. 2005. “Aspects of the Rural-Urban Transformation of Countries." Journal of Economic Geography 5: 23-42.

NPC (National Planning Commission). 2016. Growth and Transformation Plan II (GTP II) (2015/16-2019/20), Volume 1: Main Text. Addis Ababa. 
Schmidt, E., P. Dorosh, M. K. Jemal, and J. Smart. 2018. Ethiopia's Spatial and Structural Transformation: Public Policy and Drivers of Change. IFPRI-ESSP Working Paper 119. Addis Ababa: IFPRI/Ethiopia Strategy Support Program (ESSP).

Schmidt, E., and T. Thomas. 2018. Running out of Room? Discovering the Economic and Climatic Boundaries for Cropland Expansion in Ethiopia. IFPRI Discussion Paper 1723. Washington, DC: IFPRI.

UNIDO (United Nations Industrial Development Organization). 2018. "Integrated AgroIndustrial Parks (IAIPs) in Ethiopia.” Accessed March 12, 2020. www.unido.org/sites/ default/files/files/2018-08/Integrated-Agro-Industrial-Parks-in-Ethiopia-booklet.pdf.

World Bank. 2015a. Ethiopia - Urban Local Government Development Project (English). Washington, DC. http://documents.worldbank.org/curated/en/843841467991961808/ Ethiopia-Urban-Local-Government-Development-Project.

.2015b. Ethiopia Urbanization Review: Urban Institutions for a Middle-Income Ethiopia. Washington, DC. http://documents.worldbank.org/curated/en/543201468000586809/ Ethiopia-Urbanization-review-urban-institutions-for-a-middle-income-Ethiopia. 